\title{
Better the Devil You Know: The Impact of Brexit Political Uncertainty on European Financial Markets
}

\author{
Doriana Cucinelli ${ }^{1}$, Vincenzo Farina ${ }^{2}$, Paola Schwizer $^{3} \&$ Maria Gaia Soana $^{4}$ \\ ${ }^{1}$ Assistant Professor, Economics Department, University of Milano Bicocca, Milan, Italy \\ ${ }^{2}$ Associate Professor in Banking and Finance, Università di Roma Tor Vergata, Italy \\ ${ }^{3}$ Full Professor, Banking and Finance, University of Parma, Parma, Italy \\ ${ }^{4}$ Associate Professor, Banking and Finance, University of Parma, Parma, Italy \\ Correspondence: Maria Gaia Soana, Associate Professor, Banking and Finance, University of Parma, Parma, \\ Italy. E-mail: mariagaia.soana@unipr.it
}

Received: February 26, 2020

doi:10.5539/ijbm.v15n6p62
Accepted: April 1, 2020

Online Published: May 13, 2020

URL: https://doi.org/10.5539/ijbm.v15n6p62

\begin{abstract}
The paper investigates the market reaction to three different events related to Brexit through an event study analysis, i.e. the announcements of the referendum date (20 February 2016), the referendum result (23 June 2016) and the election of Theresa May as Prime Minister (11 July 2016). We study the impact of these announcements on stock prices of UK companies belonging to export- and import-oriented industries. We also investigate the influence of previous events on stock prices of European companies belonging to the same sectors. Our results show that financial markets did not perceive the announcement of the referendum date and the election of Theresa May as Prime Minister as elements of political uncertainty. However, in the days before the referendum, investors priced it as an uncertain political event. The text analysis conducted on mass media sentiment about Brexit mainly supports the results of our event studies. Stock market performance around the events depends more on industry factors than on firm-specific characteristics, for both UK and EU companies. The only exception is company size, which positively affects investor reaction.
\end{abstract}

Keywords: Brexit, event study, stock market reaction, import, export, text analysis

JEL Codes: G1, L1

\section{Introduction}

On 23 June 2016, the UK Government asked British citizens to decide whether to remain in or leave the European Union. This day made history. Voters made the decision to leave, i.e. pro Brexit, and the government started the process of managing the exit from the EU. It is very likely that the outcome of the UK referendum will shape the future of the European Union.

Brexit is critical from multiple perspectives. It is the first time an EU member State has made the decision to leave the EU, which has created a cloud of uncertainty around the future of the EU in its original structure, aims and scope. Euroscepticism is rooted in the mainly populist view of the EU as a limitation to national sovereignty; a source of bureaucracy; a non-transparent burden of rules in favor of business elites and against the working class; and an encouragement of high levels of migration enhancing the risk of terrorist attacks. Although levels of trust in Europe increased soon after the British vote, in many countries the main political parties still rail against the rigidity of EU budgetary policies. This is particularly true in Italy, which, according to the Eurobarometer survey (2019), is amongst the most Eurosceptic countries in the EU.

Moreover, Brexit is likely to be an important source of political risk, since political changes and the consequent instability usually negatively affect returns on investment. Stock markets react negatively to political uncertainty in election cycles, and in cases of any kind of change in government policies. Brexit is, in fact, a possible key determinant of market volatility. The market's reaction, soon after the referendum, could also have been boosted by a dominant pro Brexit bias, as testified by the fact only $27 \%$ of press articles were pro remain.

In fact, on the day of the referendum results, 24 June 2016, the British Pound registered a historic drop to $\$ 1.3229$, its lowest level since September 1985. The pound was down as much as $11.1 \%$ from the New York close of 
$\$ 1.4877$ on the previous day. This was almost double the next-biggest intraday drop of $5.9 \%$ on 24 October 2008, the day when stock markets around the world collapsed during the depths of the financial crisis (Peter Wells, "Historic moves for the pound on Brexit vote". Financial Times, 24 June 2016). However, in the case of Brexit, not only was the referendum day itself important. Analyses of the period from the announcement there would be a referendum to the day of the referendum reveals whether these events could be considered as features of political and economic instability. In fact, the possibility of Brexit during the period, both in UK and in the European Union, affected all economic sectors. The most important European stock indices dropped during 2016 (the FTSE 100 fell by $-3.2 \%$, the German DAX by $-6.8 \%$ and the Dow Jones Industrial Average by $-3.4 \%$ (Bloomberg, 2016), and the main cause was the increase in political instability in Europe.

At the end of November 2018, more than two years after the referendum date, in the midst of the UK negotiation with the European Commission about exit agreements, outflows from UK-focused equity funds since the Brexit vote were \$20bn (Chris Flood, Financial Times, 28 November 2018). Brexit agreements will strongly affect economic competition and trade balances throughout European countries and around the world, changing the competitive landscape and import-export flows. Hence, the economic value of UK companies showing high import and export volumes should reflect future conditions of prices and currencies' international trade.

Our study first investigates short-term stock market reaction to the referendum result, focusing on export- and import-oriented industries. It then considers whether the referendum announcement can be a driver of political uncertainty. It also investigates market reaction to another important date - the election of Theresa May -assessing whether the return to political stability under a new Prime Minister was accepted as a positive event or not.

To achieve these aims, we carry out event studies on three different events relating to Brexit, i.e. the announcements of the referendum date (20 February 2016), the referendum result (23 June 2016) and the election of Theresa May as Prime Minister (11 July 2016). We consider the impact of these events on stock prices of UK companies in export- and import-oriented industries. We also investigate the influence of previous events on stock prices of European companies belonging to the same industries. Furthermore, we conduct OLS regression analyses aimed at explaining cumulative abnormal returns using different determinants. Our findings suggest that investor reaction to different stages of Brexit depends more on industry factors than on firm-specific characteristics, both for UK and EU companies. The only exception is company size, which positively affects investor reaction in our paper as in previous literature.

To support event study evidences, we also carry out the text analysis of news referring to Brexit, extracted by the Lexis Nexis database in the category "Major World Publications". Specifically, we analyze the content of the news during the period before and after the investigated events. This helps us understand the positive or negative sentiment of mass media about Brexit and its possible consistency with stock market reaction.

Our sample is composed of 796 European listed companies. It includes 171 UK companies representing different industries, divided into import-oriented (Computer, electronic and optical products; Food products; Mining) and export-oriented (Other transport; Motor vehicles, trailers and semi-trailers; Chemicals and chemical products; Machinery and equipment; Metals and metal products) industries. The other 625 are non-UK European listed firms belonging to UK import-oriented ( 240 companies) and export-oriented (385 companies) industries. We argue that political uncertainty, as in the days before the referendum, negatively affects market prices, while a clear political decision, whatever it may be, can restore investor capacity to assess political risk and to rely on fundamentals. This expectation centers also on the hypothesis that, thanks to market efficiency, the stock market was able to absorb political uncertainty in the days before 23 June and to react positively to the appointment of Theresa May as Prime Minister, in line with the idea of "better the devil you know".

Our results show that, in the case of political uncertainty, investors react uniformly, particular firm characteristics are less important, and the abnormal stock returns depend more on the overall impact of the event on the industry than on other idiosyncratic factors.

Our study contributes to the ongoing debate about the effect of political uncertainty on financial markets. Firstly, the research analyzes the impact of Brexit on stock market returns considering the three different significant dates. Thereby, we do not focus only on the effect of the referendum result, as most previous studies have done, but we consider a longer time horizon referring to the political uncertainty period ranging from the announcement of the UK referendum to the election of the new Prime Minister.

Secondly, to the best of our knowledge, no studies have so far focused at the same time on UK sectors that import or export to EU and European industries that import or export to the UK. This allows us to analyze not only the financial consequences of Brexit on the UK, i.e. the country originating political uncertainty, but also the spillover effect on other European countries. 
Finally, this is the first paper running a text analysis of news about Brexit in order to investigate the consistency between the sentiment of mass media before and after the events and the stock market reaction.

This paper is organized as follows: Section 2 presents the literature review, Section 3 describes the research hypotheses, while the sample and the methodology are reported in Section 4. We discuss our main results in Section 5, and the additional analysis and robustness checks are described in Section 6. Finally, our conclusion and discussion are reported in Section 7.

\section{Literature Review}

Our paper is at the crossroads of two streams of literature. The first addresses the relationship between political uncertainty and the stock market, while the second focuses on stock market reaction to the Brexit referendum.

The period ranging from David Cameron's referendum announcement to the referendum date may be seen as a period of political uncertainty, relating to the possible change in the government policy (Schiereck, Kiesel \& Kolaric, 2016; Krause, Noth \& Tonzer, 2016; Smales, 2017; Dibiasi, Abberger, Siegenthaler, \& Sturm, 2018). As suggested by Pastor and Veronesi (2012), changes in government policy usually generate uncertainty in the economy and can affect stock prices, thus leading to negative stock returns. Other authors find similar results when testing the negative stock market reaction to government changes, especially in the case of political elections (Boutchkova, Doshi, Durnev, \& Molchanov, 2016; Brogaard \& Detzel, 2015). Other authors (Smales, 2015; 2016; Goodell \& Vähämaa, 2013) focus on the stock market volatility and underline that stock market uncertainty increases (decreases) as the level of uncertainty around the election day increases (decreases) while, in a case of "better the devil you know", stock market uncertainty decreases as the likelihood of the incumbent's win increases. In addition, Brogaard and Detzel (2015) and Pantzalis, Stangeland \& Turtle (2000) show that stock prices increase when political uncertainty is resolved. Furthermore, based on the information efficiency theory, Pantzalis et al. (2000) maintain that much of the uncertainty caused by political events should be absorbed before the election date. The authors find positive market reaction in the two weeks before Election Day, which may be due to both timing of the election and the country degree of political, economic and press freedom. Pantzalis et al. (2000) find that when the election result becomes more certain, stock prices start to increase again. They also show that even after the election results, political uncertainty may be resolved only partially and the stock market may need more time to process the election impact. However, where there is a significant amount of uncertainty resolution in the post-election period, positive abnormal returns would also be expected after Election Day.

With regard to Brexit as a specific case of political uncertainty, the literature is growing. Krause et al. (2016) analyze the relationship between the exit polls and the UK stock market volatility, whereas Smales (2017) investigates the impact of the political uncertainty, caused by the Brexit referendum, on the UK and German financial markets. Both studies underline increasing volatility associated with a higher uncertainty. Belke, Dubova \& Osowski (2018) find similar results and highlight that the effect of Brexit is different depending on the countries; GIIPS and the UK register the strongest losses. Moreover, with regard to the risk of contagion of political uncertainty, Campello Cortes, d'Almeida \& Kankanhalli (2018) investigate the effect of the UK referendum on American firms in terms of capital investments, employment growth and R\&D expenditures. They find those US firms that are more exposed to the UK economy are more affected by this political uncertainty, suggesting exogenously-born events can influence the financial and economic environment of countries. Only a few studies address the impact of the Brexit referendum on stock prices (Schiereck et al., 2016; Ramiah, Huy, Pham, \& Moosa, 2017; Tielman \& Schiereck, 2017; Oehler, Horn, \& Wendt, 2017; Hill, Korczak \& Korczak, 2019). Tielman and Schiereck (2017) focus on the logistics' sector and show that the negative effect of Brexit on this sector was strong in all European countries, but particularly so in the UK. The authors concentrate on the logistics' sector under the assumption that this industry would have been particularly hard hit by Brexit, because of the slower movement of goods and an increase in costs of transportation. Furthermore, they find that size and market-to-market ratio have a statistically significant positive influence on abnormal stock returns, while diversification and the involvement in road transport contribute to reducing the negative impact on stock prices. Schiereck et al. (2016) focus on the banking sector by comparing Brexit with the Lehman Brothers crisis. Their results show that Brexit was not "another Lehman Brothers moment" for banks because the short-term drop in stock market and the increase in bank CDS spreads after the Lehman crisis were stronger than in the case of Brexit. Moreover, Ramiah et al. (2017) analyze the effect of the announcement of the UK referendum results on various UK sectors over the period June-July 2016, underling different sectorial effects. Specifically, most sectors, and especially the banking industry, show negative stock market returns. Furthermore, Oehler et al. (2017) and Hill et al. (2019) investigate the impact of Brexit on UK firms, distinguishing between more and less internationalized firms. The authors find that the UK's international firms show higher positive stock returns than domestic firms, as international activities are a diversification mechanism for domestic risk. However, Oehler et al. (2017) underline 
that this positive effect emerges only on the first trading day after the referendum result. In the following days, indeed, internationalization ceases to be significant. Finally, Aristeidis and Elias (2018) investigate the possible contagion effect relating to the referendum result. They find that, although in the very short-term the reaction of stock markets all over the world was negative, after just a few days most of them had fully recovered their losses, indicating that there was in fact no contagion effect. These results are in contrast with Campello Cortes, d'Almeida \& Kankanhalli (2018) who find a possible contagion risk on the real economy.

This evidence appears to support the hypothesis that the result of the referendum surprised stock markets both in the UK and in other countries, but only in the very short-term. In the days following the Brexit announcement, financial markets returned to a "normal" volatility. As observed by Baur, Dimpfl \& Treepongkaruna (2018), Brexit caused a storm, but no storm damage. Also, Shahzad, Rubbaniy, Lensvelt \& Bhatti (2019), analyzing 27 different events linked to Brexit, both before and after the referendum, find a negative and significant market reaction before the referendum and no significant market reaction post-referendum. As soon as the UK's future economic relations with EU started to take shape, the positive side of Brexit emerged.

As suggested by Levy, Aslan \& Bironzo (2016) and Moore and Ramsey (2017), media coverage during the referendum campaign was very strong in the UK and played a very important role. In particular, Levy et al. (2016), analyzing the period ranging from the date of Cameron's vote announcement to 23 June 2016, find that the number of articles published on the referendum increased dramatically in the last week. In this week, most of the press was pro exit, thus creating a dominant "pro Brexit bias".

\section{Research Hypotheses}

In light of literature analyzed, our research studies the stock market reaction to different events related to Brexit, i.e. the announcements of the referendum date, the referendum result and the election of Theresa May as Prime Minister. It focuses on UK companies belonging to export- and import-oriented industries and on other European companies belonging to the same industries. We test the following hypotheses.

Our first hypothesis assumes that financial markets, both in the UK and in other European countries, on 20 February 2016 did not consider the Brexit referendum as an uncertain political event. We base this on the evidence that, at that time, "remain" received high volumes of coverage in the UK press (Moore and Ramsay, 2017) and thus, among other things, the thought was "remain" would be the most likely outcome of the vote. Therefore, we do not consider the announcement of the referendum date as marking the beginning of a period of political uncertainty.

$\mathrm{H}_{1}$ : On the announcement of the referendum date, 20 February 2016, investors assumed that the final result would be "remain", thus not considering the referendum an uncertain political event.

However, in the days before the vote, and especially during the last week, a high level of uncertainty on the referendum result emerged (Shahzad et al., 2019). In that period, the UK press also stimulated this uncertainty, as demonstrated by Levy et al. (2016). For this reason, our second hypothesis is the following:

$\mathrm{H}_{2}$ : On 23 June 2016, the referendum date, investors perceived the final result as ambiguous, thus considering the referendum an uncertain political event.

Following Cameron's resignation, Theresa May won a leadership election on 11 July 2016, becoming the UK's second female Prime Minister in history. Mrs. May, who took a firm lead in the first round of voting, was perceived as a trustworthy and credible politician, both in the UK and in other European countries. She sent the message to the world that "together with British people, a better Britain would be built". In this context, our third hypothesis is the following:

$\mathrm{H}_{3}$ : Investors did not consider the election of Theresa May as Prime Ministers, on 11 July 2016, as an uncertain political event.

Finally, the effects of Brexit differ among industries (Jackowicz, Kozłowski \& Podgórski, 2017; Ramiha et al., 2017). On this point, Davies and Studnicka (2018) find a heterogeneous impact. In particular, they show that, due to the depreciation of the pound, more export-oriented companies were affected less by the negative effect of Brexit. They also demonstrate that firms with a global value chain more oriented towards the European markets suffered more than the market as a whole. These results suggest a diversified effect of Brexit on companies operating in different sectors and markets. Moreover, Jackowicz et al. (2017) find that firm fundamentals modestly influenced investor reaction to the referendum results. Our fourth hypothesis is, thus, the following:

$\mathrm{H}_{4}$ : Investor reaction to events related to Brexit depends more on the industry than on company specific characteristics. 


\section{Sample and Methodology}

\subsection{Event Study Methodology}

Our paper tests the effects of three different events related to Brexit, i.e. the announcements of the referendum date (on 20 February 2016), the referendum result (on 23 June 2016) and the election of Theresa May as Prime Minister (on 11 July 2016), on stock prices of UK companies belonging to export- and import-oriented industries. We also investigate the influence of previous events on stock prices of European companies belonging to the same industries.

We conducted the analyses using the event study technique (MacKinlay, 1997). Specifically, we calculate abnormal returns following the announcements of the three events related to Brexit; it is thought that these explain stock return changes. Abnormal returns are estimated as the difference between stock returns registered from the listed company $i$ on day t, i.e. the day when the event is announced, and the expected returns that the stock would have registered in the case that no event happened. Expected returns are calculated using Sharpe's (1963) market model, as suggested by previous literature (Campbell, Lo, \& MacKinley, 1997).

$$
\hat{R}_{i, t}=\alpha_{i}+\beta_{i} R_{m k t, t}+\varepsilon_{i, t}
$$

where $\widehat{\boldsymbol{R}}_{\boldsymbol{i}, \boldsymbol{t}}$ is the stock return of company i on day $\mathrm{t}$; $\alpha \mathrm{i}$ is the intercept of the regression line; $\beta \mathrm{i}$ is the slope of the regression line; $\mathrm{R}_{\mathrm{mk} t, \mathrm{t}}$ is the national market index return on day $\mathrm{t}$; $\varepsilon \mathrm{i}, \mathrm{t}$ is the random error. Some OLS regressions of $\widehat{\boldsymbol{R}}_{\boldsymbol{i}, \boldsymbol{t}}$ on $\mathrm{R}_{\mathrm{mkt}}$ for 250 days (i.e. from the 270 th to the 21 st day before the event announcement) imply the estimate of the $\alpha i$ and $\beta i$ coefficients. We define the date of the event related to Brexit as Day 0 , and the event window as the period ranging from $-\tau_{1}$ days before and $+\tau_{2}$ days after Day 0 . We consider different window lengths, both before and after Day 0, because it is possible that the market could price some information before its official announcement. We estimate the abnormal return $\left(\mathrm{AR}_{\mathrm{i}, t}\right)$ due to each event for the company $\mathrm{i}$ on Day $\mathrm{t}$ as follows:

$$
A R_{i, t}=R_{i, t}-\left(\hat{\alpha}_{i}+\hat{\beta}_{i} R_{m k t, t}\right)
$$

Then we aggregate the abnormal returns for all n company stocks and calculate the average abnormal return $\left(\overline{A R}_{t}\right)$ :

$$
\overline{A R}_{t}=\frac{1}{n} \sum_{i=1}^{n} A R_{i, t}
$$

Moreover, we estimate the cumulative abnormal return $\boldsymbol{C A R}_{\boldsymbol{i}}\left(\boldsymbol{\tau}_{1}, \boldsymbol{\tau}_{2}\right)$ for each stock i by summing all $\mathrm{AR}_{\mathrm{i}, \mathrm{t}}$ within the event period $\left[\boldsymbol{\tau}_{1}, \boldsymbol{\tau}_{2}\right]$ :

$$
\operatorname{CAR}_{i}\left(\tau_{1}, \tau_{2}\right)=\sum_{t=\tau_{1}}^{\tau_{2}} A R_{i, t}
$$

and calculate the mean CARs in the different event windows $\left(\overline{\boldsymbol{C A R}}\left(\boldsymbol{\tau}_{1}, \boldsymbol{\tau}_{2}\right)\right)$ :

$$
\overline{\operatorname{CAR}}_{i}\left(\tau_{1}, \tau_{2}\right)=\frac{1}{n} \sum_{i=1}^{n} \operatorname{CAR}\left(\tau_{1}, \tau_{2}\right)
$$

The statistical significance of mean CARs is verified using two parametric and one non-parametric test. The first parametric test $\left(T_{1}\right)$ suggested by Campbell et al. (1997) is widely used in previous literature. The formula is as follows:

$$
T_{1}=\frac{\overline{C A R}\left(\tau_{1}, \tau_{2}\right)}{\left[\widehat{\sigma}^{2}\left(\tau_{1}, \tau_{2}\right)\right]^{\frac{1}{2}}} \approx N(0,1)
$$

However, Harrington and Shrider (2007) demonstrate that $\mathrm{T}_{1}$ can show bias in a short time period. For this reason, we also calculate a second parametric test $\left(\mathrm{T}_{2}\right)$ that is more robust to an event-induced variance increase (Boehmer, Musumeci \& Poulsen, 1991):

$$
T_{2}=\sqrt{N} \frac{\overline{\operatorname{SCAR}}\left(\tau_{1}, \tau_{2}\right)}{\sqrt{\frac{1}{N-1} \sum\left(\operatorname{SCAR}\left(\tau_{1}, \tau_{2}\right)-\overline{S C A R}\left(\tau_{1}, \tau_{2}\right)\right)^{2}}} \approx T\left(0, \frac{g}{g-2}\right)
$$

with $\mathrm{g}>2$, where $\mathrm{N}$ is the number of stocks and $\boldsymbol{S} \boldsymbol{C A \boldsymbol { R } _ { \boldsymbol { i } }}\left(\boldsymbol{\tau}_{\mathbf{1}}, \boldsymbol{\tau}_{2}\right)$ is the standardized abnormal return on security i at day t. We follow the methodology suggested by Mikkelson and Partch (1988) in order to estimate $\boldsymbol{S C A R}_{\boldsymbol{i}}\left(\boldsymbol{\tau}_{1}, \boldsymbol{\tau}_{\boldsymbol{2}}\right)$ :

$$
S C A R_{i, t}=\frac{\operatorname{CAR}_{i}\left(\tau_{1}, \tau_{2}\right)}{\sqrt{\sigma_{l}} \sqrt{T_{S}+\frac{T_{S}^{2}}{T}+\frac{\tau_{i=\tau_{1}}^{2}\left(R_{m, t}-T_{S} \overline{R_{m}}\right)}{\sum_{i=1}^{T}\left(R_{m, t}-\overline{R m}\right)}}}
$$

where $\tau_{1}$ and $\tau_{2}$ are the first and last days in the event window, respectively. $\boldsymbol{C A R}_{\boldsymbol{i}}\left(\boldsymbol{\tau}_{1}, \boldsymbol{\tau}_{2}\right)$ is the cumulative abnormal return of stock $\mathrm{i}$ in the event window $\left(\boldsymbol{\tau}_{1}, \boldsymbol{\tau}_{2}\right) . \overline{\boldsymbol{R}_{\boldsymbol{m}}}$ is the mean return on market index in the estimation period. $\widehat{\sigma}_{\boldsymbol{t}}$ is the estimated standard deviation of abnormal return on stock $\mathrm{i}$. $\mathrm{T}$ is the number of days in the estimation period. Lastly, $\mathrm{T}_{\mathrm{s}}$ is the number of days in the event window. $\mathrm{T}_{2}$ shows a T-distribution with $\mathrm{T}-2$ degrees 
of freedom, and converges to a unit normal. In order to confirm the results obtained by $\mathrm{T}_{1}$ and $\mathrm{T}_{2}$, we also calculate the non-parametric test suggested by Campbell et al. (1997) and MacKinlay (1997):

$$
T_{3}=\left[\frac{N^{(+/-)}}{N}-0.5\right] \frac{N^{\frac{1}{2}}}{0.5} \approx N(0,1)
$$

where $\mathrm{N}$ is the number of events and $\mathrm{N}(+) / \mathrm{N}(-)$ is the number of events with a positive/negative $\mathrm{CAR}$. We consider those CARs that passed all the three tests described above as statistically significant.

\subsection{The Regression Model}

In the second stage of our empirical analysis, we conducted some regressions in order to explain CARs using different determinants. We run OLS regressions with robust standard errors and sector dummy variables. The construction of our models is as follows:

$$
y_{i}=\alpha+\beta_{1} X_{i, \mathrm{t}}+\beta_{2} \Omega_{\mathrm{i}, \mathrm{t}}++\beta_{3} \text { COUNTRY_FE } \mathrm{F}_{\mathrm{i}, \mathrm{j}}, \varepsilon_{i} \quad i=1, \ldots, N
$$

where subscript $\mathrm{i}$ denotes the cross-section dimension, and $\mathrm{t}$ and $\mathrm{j}$, respectively, the time and the country of the country specific variable. The dependent variable is the statistically significant cumulative abnormal return (CAR) observed in the event study analysis. The $\mathrm{X}$ vector refers to the firm specific characteristics in terms of balance sheet ratios, while the vector $\Omega$ includes the dummies referring to the sector. Finally, in order to control for the differences among European countries, we insert a further vector (COUNTRY FE) including a series of dummy variables referring to the country; we insert one dummy variable for each observed country.

With regard to the $\mathrm{X}$ vector, as suggested by numerous authors (see e.g. Jackowicz et al., 2017), we consider the following firm-specific characteristics: i) the return on sales (ROS) as measure of profitability; ii) the share of current assets on total assets (CURRENT_RATIO) as proxy of liquidity; iii) the equity over total assets ratio (E_TA) as measure of capitalization; and iv) finally, the natural logarithm of total revenues (SIZE) as proxy of firm size. Table 1 reports descriptive statistics, while correlations are presented in Table 2. Our results show no high Pearson correlation among independent variables; this means that they are suitable for further analysis.

Referring to the $\Omega$ vector, first we distinguish between UK import-oriented companies (UK import) and other European import-oriented firms (No UK import). We insert three dummy variables referring to different industries: i) computer, electronic and optical products (TECNOLOGY), ii) food products (FOOD), and iii) mining (MINING). Second, we distinguish between UK export-oriented companies (UK export) and other European export-oriented firms (No UK export). We insert five dummy variables referring to different industries: i) other transport (TRANSPORT), ii) motor vehicles, trailers and semi-trailers (VEHICLES), iii) chemicals and chemical products (CHEMICAL), iv) machinery and equipment (MACHINERY), and v) metals and metal products (METAL).

We consider three different events related to Brexit. For each event, we test the regression model (10) on the event windows showing a statistical significance in the event study analysis. We run regressions on all our four subsamples: a) UK import; b) No UK import; c) UK export; and finally, d) No UK export. 
Table 1. Descriptive statistics

\begin{tabular}{|c|c|c|c|c|c|c|c|c|c|c|c|c|c|c|c|c|c|c|c|c|}
\hline \multirow[b]{2}{*}{ Variable } & \multicolumn{5}{|c|}{ UK IMPORT } & \multicolumn{5}{|c|}{ UK EXPORT } & \multicolumn{5}{|c|}{ NO UK IMPORT } & \multicolumn{5}{|c|}{ NO UK EXPORT } \\
\hline & obs & Mean & Std. Dev. & Min & Max & obs & Mean & Std. Dev. & Min & Max & obs & Mean & Std. Dev. & Min & Max & obs & Mean & Std. Dev. & Min & Max \\
\hline $\mathrm{EW}(-5 ;-1)$ & 90 & -0.030 & 0.058 & -0.248 & 0.132 & 81 & -0.028 & 0.065 & -0.205 & 0.189 & 238 & -0.008 & 0.052 & -0.317 & 0.272 & 385 & 0.001 & 0.055 & -0.208 & 0.419 \\
\hline $\mathrm{EW}(-3 ;-1)$ & 90 & -0.024 & 0.051 & -0.200 & 0.086 & 81 & -0.024 & 0.062 & -0.210 & 0.180 & 238 & -0.002 & 0.037 & -0.241 & 0.140 & 385 & 0.000 & 0.048 & -0.247 & 0.419 \\
\hline $\operatorname{EW}(0 ;+5)$ & 90 & 0.015 & 0.131 & -0.480 & 0.328 & 81 & 0.045 & 0.125 & -0.576 & 0.435 & 238 & 0.005 & 0.148 & -2.013 & 0.354 & 385 & 0.009 & 0.085 & -0.412 & 0.656 \\
\hline $\mathrm{EW}(0 ;+3)$ & 90 & 0.007 & 0.113 & -0.482 & 0.274 & 81 & 0.022 & 0.110 & -0.540 & 0.303 & 238 & 0.006 & 0.067 & -0.344 & 0.376 & 385 & 0.005 & 0.065 & -0.348 & 0.371 \\
\hline $\operatorname{EW}(0 ;+10)$ & 90 & 0.017 & 0.084 & -0.265 & 0.286 & 81 & 0.030 & 0.073 & -0.157 & 0.192 & 238 & 0.001 & 0.063 & -0.420 & 0.292 & 385 & 0.006 & 0.056 & -0.374 & 0.288 \\
\hline ROS & 80 & -24.57 & 12.136 & -95.120 & 34.753 & 67 & -21.161 & 11.711 & -88.400 & 26.974 & 234 & -23.459 & 22.851 & -33.169 & 12.083 & 351 & -94.118 & 16.565 & -29.950 & 65.018 \\
\hline E_TA & 89 & 53.401 & 33.823 & -144.673 & 98.195 & 79 & 61.885 & 25.634 & -14.733 & 99.907 & 237 & 41.813 & 78.542 & -102.184 & 93.854 & 363 & 45.363 & 26.406 & -177.441 & 99.865 \\
\hline SIZE & 83 & 11.513 & 3.144 & 3.016 & 16.958 & 68 & 11.946 & 3.749 & 0.998 & 19.310 & 236 & 12.364 & 2.503 & 2.639 & 18.698 & 358 & 12.212 & 2.958 & -0.348 & 19.212 \\
\hline CURRENT & 89 & 2.734 & 2.562 & 0.061 & 13.003 & 79 & 5.150 & 10.323 & 0.432 & 61.909 & 237 & 2.062 & 1.635 & 0.070 & 18.609 & 360 & 2.141 & 3.446 & 0.012 & 61.162 \\
\hline TRANSPORT & 90 & 0.089 & 0.286 & 0.000 & 1.000 & & - & & - & - & - & - & - & - & - & 385 & 0.098 & 0.298 & 0.000 & 1.000 \\
\hline VEHICLES & 90 & 0.078 & 0.269 & 0.000 & 1.000 & - & - & - & - & - & - & & - & & & 385 & 0.132 & 0.339 & 0.000 & 1.000 \\
\hline CHEMICAL & 90 & 0.356 & 0.481 & 0.000 & 1.000 & - & - & - & - & - & - & - & - & - & - & 385 & 0.238 & 0.426 & 0.000 & 1.000 \\
\hline MACHINERY & 90 & 0.144 & 0.354 & 0.000 & 1.000 & - & - & - & - & - & - & - & - & - & - & 385 & 0.354 & 0.479 & 0.000 & 1.000 \\
\hline METAL & 90 & 0.333 & 0.474 & 0.000 & 1.000 & - & - & - & - & - & - & - & - & - & - & 385 & 0.178 & 0.383 & 0.000 & 1.000 \\
\hline FOOD & & - & - & - & - & 81 & 0.123 & 0.331 & 0.000 & 1.000 & 238 & 0.248 & 0.433 & 0.000 & 1.000 & - & - & - & & \\
\hline MINING & & & - & - & - & 81 & 0.543 & 0.501 & 0.000 & 1.000 & 238 & 0.134 & 0.342 & 0.000 & 1.000 & - & - & - & - & - \\
\hline TECNOLOGY & & - & - & - & - & 81 & 0.333 & 0.474 & 0.000 & 1.000 & 238 & 0.618 & 0.487 & 0.000 & 1.000 & - & . & - & - & . \\
\hline
\end{tabular}

Notes. Table 1 reports the descriptive statistics of the variables used in the regression model. We distinguish among four different subsamples: UK companies import-oriented (UK import), UK companies export-oriented (UK export), other European companies import-oriented (No UK import), other European companies export-oriented (No UK export).

\section{Table 2. Correlation matrix}

Panel A)

\begin{tabular}{|c|c|c|c|c|c|c|c|c|c|c|c|c|c|c|}
\hline & \multicolumn{7}{|c|}{ UK IMPORT } & \multicolumn{7}{|c|}{ NO UK IMPORT } \\
\hline & ROS & E_TA & SIZE & CURRENT & FOOD & MINING & TECHNOLOGY & ROS & E_TA & SIZE & CURRENT & FOOD & MINING & TECHNOLOGY \\
\hline ROS & 1.000 & & & & & & & 1.000 & & & & & & \\
\hline E_TA & -0.297 & 1.000 & & & & & & 0.036 & 1.000 & & & & & \\
\hline SIZE & 0.524 & -0.510 & 1.000 & & & & & 0.272 & 0.096 & 1.000 & & & & \\
\hline CURRENT & -0.351 & 0.407 & -0.458 & 1.000 & & & & 0.122 & 0.221 & -0.161 & 1.000 & & & \\
\hline FOOD & 0.075 & -0.214 & 0.155 & -0.106 & 1.000 & & & 0.069 & 0.050 & 0.198 & -0.118 & 1.000 & & \\
\hline MINING & -0.190 & 0.139 & -0.282 & 0.200 & -0.401 & 1.000 & & -0.220 & 0.006 & 0.074 & -0.011 & -0.224 & 1.000 & \\
\hline TECHNOLOGY & 0.141 & 0.015 & 0.177 & -0.129 & -0.323 & -0.738 & 1.000 & 0.092 & -0.049 & -0.228 & 0.113 & -0.733 & -0.499 & 1.000 \\
\hline
\end{tabular}


Panel B)

\begin{tabular}{|c|c|c|c|c|c|c|c|c|c|c|c|c|c|c|c|c|c|c|}
\hline & \multicolumn{9}{|c|}{ UK EXPORT } & \multicolumn{9}{|c|}{ NO UK EXPORT } \\
\hline & ROS & $\mathrm{E}_{-} \mathrm{TA}$ & SIZE & CURRENT & TRANSPORT & CAR & CHEMICAL & $\begin{array}{l}\text { MACHI- } \\
\text { NERY }\end{array}$ & METAL & ROS & E_TA & SIZE & CURRENT & TRANSPORT & CAR & CHEMICAL & MACHINERY & METAL \\
\hline ROS & 1.000 & & & & & & & & & 1.000 & & & & & & & & \\
\hline E_TA & -0.122 & 1.000 & & & & & & & & 0.020 & 1.000 & & & & & & & \\
\hline SIZE & 0.445 & -0.347 & 1.000 & & & & & & & 0.168 & -0.204 & 1.000 & & & & & & \\
\hline CURRENT & -0.119 & 0.537 & -0.373 & 1.000 & & & & & & -0.016 & 0.300 & -0.127 & 1.000 & & & & & \\
\hline TRANSPORT & 0.071 & -0.101 & 0.164 & -0.046 & 1.000 & & & & & 0.023 & -0.036 & 0.031 & -0.040 & 1.000 & & & & \\
\hline VEICHELES & 0.020 & -0.124 & 0.032 & -0.083 & -0.103 & 1.000 & & & & -0.128 & -0.106 & 0.105 & -0.040 & -0.129 & 1.000 & & & \\
\hline CHEMICAL & -0.195 & 0.171 & -0.293 & 0.105 & -0.265 & -0.246 & 1.000 & & & 0.023 & 0.067 & -0.079 & -0.008 & -0.182 & -0.210 & 1.000 & & \\
\hline MACHINERY & 0.091 & -0.018 & 0.130 & -0.023 & -0.147 & -0.136 & -0.350 & 1.000 & & 0.055 & 0.019 & 0.013 & -0.027 & -0.253 & -0.291 & -0.413 & 1.000 & \\
\hline METAL & 0.079 & -0.026 & 0.083 & -0.011 & -0.199 & -0.185 & -0.475 & -0.263 & 1.000 & 0.001 & 0.023 & -0.046 & 0.109 & -0.155 & -0.179 & -0.254 & -0.352 & 1.000 \\
\hline
\end{tabular}

Notes. Panel A) reports the correlation matrix that refers to the import-oriented firms, while Panel B) reports the correlation matrix that refers to the export-oriented firms.

\subsection{The Sample}

The sample consists of 796 European listed companies, as shown in Table 3. 171 are UK companies: 81 belong to import-oriented industries (Computer, electronic and optical products; Food products; Mining) and 90 to export-oriented industries (Other transport; Motor vehicles, trailers and semi-trailers; Chemicals and chemical products; Machinery and equipment; Metals and metal products). The other 625 are non-UK European listed firms belonging to UK import-oriented (240 companies) and export-oriented (385 companies) industries.

In order to avoid biases in the estimation of stock market performance, we exclude from our database all companies that announced price relevant information from 10 days before to 10 days after "Day 0 ".

Table 3. The sample by industry

\begin{tabular}{llll}
\hline Industry & & UK & Other European countries \\
\hline \multirow{4}{*}{ UK export-oriented industries } & Other transport & 38 \\
& Motor vehicles, trailers and semi-trailers & 7 & 53 \\
& Chemicals and chemical products & 32 & 92 \\
& Machinery and equipment & 13 & 134 \\
& Metals and metal products & 30 & 69 \\
& Computer, electronic and optical products & 27 & 147 \\
UK import-oriented industries & Food products & 10 & 60 \\
& Mining & 44 & 32 \\
\hline \multirow{2}{*}{ Total } & & $\mathbf{1 7 1}$ & $\mathbf{6 2 5}$ \\
\hline
\end{tabular}

Notes. Table 3 shows the sample over different industries. Source: Orbis database.

\section{Results}

\subsection{Event Study}

In order to verify stock price reactions to the three different events related to Brexit, i.e. the announcements of the referendum date, the referendum result and the election of Theresa May as Prime Minister, we carried out different event studies. 
The first event we investigate is the announcement of the referendum date made on 20 February 2016. Results on UK companies and other European firms are reported in Tables 4 and 5, respectively.

Table 4. The referendum announcement: the effect on UK companies

\begin{tabular}{lllllllllll}
\hline & \multicolumn{1}{c}{$\begin{array}{l}\text { Panel } A \text { ) } \\
\text { Export-oriented industries }\end{array}$} & \multicolumn{9}{c}{$\begin{array}{l}\text { Panel B) } \\
\text { Import-oriented industries }\end{array}$} \\
\hline Event window & Mean CAR & $\begin{array}{l}\text { Number } \\
\text { of firms }\end{array}$ & $\mathrm{T}_{1}$ & $\mathrm{~T}_{2}$ & $\mathrm{~T}_{3}$ & Mean CAR & $\begin{array}{l}\text { Number } \\
\text { of firms }\end{array}$ & $\mathrm{T}_{1}$ & $\mathrm{~T}_{2}$ & $\mathrm{~T}_{3}$ \\
\hline$(-10,-1)$ & $0.041^{*}$ & 90 & 2.723 & 1.711 & 1.476 & $0.020^{*}$ & 81 & 1.874 & 1.413 & 1.444 \\
$(-5,-1)$ & $0.018^{* *}$ & 90 & 1.991 & 2.525 & 2.530 & $0.046^{* * *}$ & 81 & 6.398 & 5.850 & 4.778 \\
$(-3,-1)$ & $0.022^{* * *}$ & 90 & 3.663 & 2.807 & 2.319 & $0.033^{* * *}$ & 81 & 5.793 & 4.021 & 5.222 \\
$(0,10)$ & $0.070^{* *}$ & 90 & 3.746 & 1.924 & 2.438 & $0.074^{* * *}$ & 81 & 3.881 & 4.030 & 2.778 \\
$(0,5)$ & $0.017^{*}$ & 90 & 1.748 & 1.949 & 1.590 & $0.026^{*}$ & 81 & 1.906 & 1.622 & 1.565 \\
$(0,3)$ & $0.019^{* * *}$ & 90 & 2.381 & 2.835 & 2.558 & $0.023^{* *}$ & 81 & 2.083 & 1.814 & 2.138 \\
$(0,1)$ & $0.020^{* * *}$ & 90 & 2.522 & 2.404 & 3.967 & $0.023^{*}$ & 81 & 2.409 & 1.442 & 1.937 \\
\hline
\end{tabular}

Notes. Table 4 shows the results of event studies carried out on 171 listed UK companies related to the announcement of the referendum date (on 20 February 2016). 90 companies belong to UK export-oriented sectors, and 81 companies belong to UK import-oriented sectors. We measured the predicted normal bank returns using the market model. The CAR statistical significance is verified using three tests $\left(T_{1}, T_{2}\right.$ and $\mathrm{T}_{3}$ ), reported in Equations (6), (7) and (9). ${ }^{* * *}{ }^{* * *}$ denote the statistical significance at $10 \%, 5 \%$ and $1 \%$, respectively (one-tailed test).

Table 5. The referendum announcement: the effect on non-UK companies

\begin{tabular}{|c|c|c|c|c|c|c|c|c|c|c|}
\hline Event window & $\begin{array}{l}\text { Panel A) } \\
\text { Export } \\
\text { Mean CAR }\end{array}$ & $\begin{array}{l}\text { Number } \\
\text { of firms }\end{array}$ & $\mathrm{T}_{1}$ & $\mathrm{~T}_{2}$ & $\mathrm{~T}_{3}$ & $\begin{array}{l}\text { Panel B) } \\
\text { Import } \\
\text { Mean CAR }\end{array}$ & $\begin{array}{l}\text { Number } \\
\text { of firms }\end{array}$ & $\mathrm{T}_{1}$ & $\mathrm{~T}_{2}$ & $\mathrm{~T}_{3}$ \\
\hline$(-10,-1)$ & -0.006 & 384 & -0.719 & -0.095 & 0.306 & -0.010 & 240 & -1.621 & -1.214 & 1.936 \\
\hline$(-5,-1)$ & $0.018^{* * *}$ & 384 & 5.215 & 4.494 & 5.307 & $0.016^{* * *}$ & 240 & 2.689 & 5.706 & 5.164 \\
\hline$(-3,-1)$ & $0.009^{* *}$ & 384 & 2.953 & 1.809 & 2.347 & $0.013^{* * *}$ & 240 & 3.189 & 3.824 & 4.002 \\
\hline$(0,10)$ & $0.036^{* * *}$ & 384 & 5.511 & 5.014 & 5.001 & $0.028^{* * *}$ & 240 & 2.608 & 4.149 & 2.324 \\
\hline$(0,5)$ & $0.013^{* *}$ & 384 & 2.649 & 2.294 & 3.980 & $0.015^{* *}$ & 240 & 2.130 & 3.960 & 3.873 \\
\hline$(0,3)$ & $0.006^{*}$ & 384 & 1.549 & 1.693 & 3.219 & $0.012^{* *}$ & 240 & 2.185 & 2.377 & 3.241 \\
\hline$(0,1)$ & $0.011^{*}$ & 384 & 2.873 & 1.424 & 4.662 & $0.014^{*}$ & 240 & 3.279 & 1.398 & 4.926 \\
\hline
\end{tabular}

Notes. Table 5 shows the results of event studies carried out on 624 listed European companies related to the announcement of the referendum date (on 20 February 2016). 384 companies belong to UK export-oriented sectors, while 240 companies belong to UK import-oriented sectors. We measured the predicted normal bank returns using the market model. The CAR statistical significance is verified using three tests $\left(\mathrm{T}_{1}, \mathrm{~T}_{2}\right.$ and $\left.\mathrm{T}_{3}\right)$, reported in Equations (6), (7) and (9). ${ }^{*}{ }^{* *},{ }^{* * *}$ denote the statistical significance at $10 \%, 5 \%$ and $1 \%$, respectively (one-tailed test).

Our findings show positive and statistically significant mean CARs in almost all the investigated event windows. Focusing on UK export-oriented companies (Table 4, Panel A), we identify statistically significant mean CARs of $4.1 \%, 1.8 \%$ and $2.2 \%$ in the event windows $(-10,-1),(-5,-1)$ and $(-3,-1)$, respectively. We obtained similar CARs on UK import-oriented companies (Table 4, Panel B) in the same event windows. We interpret these significant results before the event date as evidence that the information on the referendum date probably circulated some days before its official announcement. In our opinion, the UK financial market positively priced such information, as on 20 February 2016, the Prime Minister David Cameron said he would be campaigning to remain in a reformed EU. In that period, the thought was "remain" would be the most likely outcome and received high volumes of coverage across most UK economic publications, as shown by the analysis by Moore and Ramsay (2017).

Moreover, the event windows following 20 February 2016 also show positive and statistically significant CARs related to both UK export-oriented (Table 4, Panel A) and import-oriented (Table 4, Panel B) companies. This can also explain these positive results considering that in February 2016 the market did not consider the referendum 
outcome as an uncertain event. Results of our text analysis do not support this idea, as the news published in the ten days following 20 February is mainly negative. In this view, our results are consistent with previous evidences by Pantzalis, Stangeland \& Turtle (2000), Goodel and Vähämaa (2013), Brogaard and Detzel (2015) and Samles $(2015,2016)$.

We also investigate the effect of the announcement of the referendum date on stock prices of other European companies belonging to UK export- and import-oriented industries. Our findings, reported in Table 5, show positive and statistically significant mean CARs in all the investigated event windows except $(-10,-1)$. This means that other European financial markets, like the UK, positively priced the information on the referendum call. It could also explain these results considering the thought was the "remain" outcome would be very likely and, consequently, political uncertainty was very low. Results of our text analysis partially support this idea, as mass media sentiment referred to news about Brexit published in the ten days before 20 February as mainly positive, but largely negative after the Day 0.

These results lead us to accept Hypothesis 1 both in relation to the UK and other-European countries' financial markets.

The second event we investigate is the referendum vote, which took place on 23 June 2016 . We report the results in Tables 6 and 7, respectively.

Table 6. The referendum vote: the effect on UK companies

\begin{tabular}{|c|c|c|c|c|c|c|c|c|c|c|}
\hline & $\begin{array}{l}\text { Panel A) } \\
\text { Export-orien }\end{array}$ & ted industries & & & & $\begin{array}{l}\text { Panel B) } \\
\text { Import-orien }\end{array}$ & ted industries & & & \\
\hline Event window & Mean CAR & Number of firms & $\mathrm{T}_{1}$ & $\mathrm{~T}_{2}$ & $\mathrm{~T}_{3}$ & Mean CAR & Number of firms & $\mathrm{T}_{1}$ & $\mathrm{~T}_{2}$ & $\mathrm{~T}_{3}$ \\
\hline$(-10,-1)$ & $-0.040^{* * *}$ & 89 & -4.070 & -4.428 & 3.838 & $-0.035^{* * *}$ & 81 & -3.620 & -3.996 & 3.222 \\
\hline$(-5,-1)$ & $-0.030^{* * *}$ & 89 & -4.958 & -4.535 & 4.558 & $-0.028^{* * *}$ & 81 & -3.901 & -4.184 & 3.444 \\
\hline$(-3,-1)$ & $-0.024^{* * *}$ & 89 & -4.352 & -2.856 & 3.624 & $-0.024^{* * *}$ & 81 & -3.532 & -3.101 & 3.222 \\
\hline$(0,10)$ & $0.052^{* * *}$ & 89 & 2.874 & 3.743 & 3.286 & $0.044^{* *}$ & 81 & 2.042 & 3.970 & 3.222 \\
\hline$(0,5)$ & 0.015 & 89 & 1.068 & 1.525 & 0.742 & $0.045^{* * *}$ & 81 & 3.242 & 4.031 & 3.889 \\
\hline$(0,3)$ & 0.007 & 89 & 0.559 & 0.922 & 0.318 & $0.026^{* *}$ & 81 & 2.159 & 1.688 & 2.138 \\
\hline$(0,1)$ & 0.017 & 89 & 1.896 & 0.100 & 1.166 & $0.033^{* *}$ & 81 & 4.211 & 1.963 & 3.488 \\
\hline
\end{tabular}

Notes: Table 6 shows the results of event studies carried out on 170 listed UK companies related to the referendum vote (23 June 2016 ). 89 companies belong to UK export-oriented sectors, while 81 companies belong to UK import-oriented sectors. We measured the predicted normal bank returns using the market model. The CAR statistical significance is verified using three tests $\left(T_{1}, T_{2}\right.$ and $\left.T_{3}\right)$, reported in Equations (6), (7) and (9). ${ }^{*},{ }^{* *},{ }^{* * *}$ denote the statistical significance at $10 \%, 5 \%$ and $1 \%$, respectively (one-tailed test).

Table 7. The referendum vote: the effect on non-UK companies

\begin{tabular}{|c|c|c|c|c|c|c|c|c|c|c|}
\hline & $\begin{array}{l}\text { Panel A) } \\
\text { Export }\end{array}$ & & & & & $\begin{array}{l}\text { Panel B) } \\
\text { Import }\end{array}$ & & & & \\
\hline $\begin{array}{l}\text { Event } \\
\text { window }\end{array}$ & Mean CAR & $\begin{array}{l}\text { Number of } \\
\text { firms }\end{array}$ & $\mathrm{T}_{1}$ & $\mathrm{~T}_{2}$ & $\mathrm{~T}_{3}$ & Mean CAR & $\begin{array}{l}\text { Number } \\
\text { of firms }\end{array}$ & $\mathrm{T}_{1}$ & $\mathrm{~T}_{2}$ & $\mathrm{~T}_{3}$ \\
\hline$(-10,-1)$ & -0.008 & 385 & -2.185 & -0.056 & 3.202 & $-0.027^{* * *}$ & 238 & -3.619 & -5.201 & 5.445 \\
\hline$(-5,-1)$ & 0.001 & 385 & 0.491 & 0.640 & -0.864 & $-0.008^{* * *}$ & 238 & -2.414 & -3.247 & 2.463 \\
\hline$(-3,-1)$ & 0.000 & 385 & 0.202 & -0.101 & -1.677 & -0.002 & 238 & -0.913 & -2.523 & 0.259 \\
\hline$(0,10)$ & $0.014^{* *}$ & 385 & 2.137 & 1.968 & 1.372 & $0.013^{* *}$ & 238 & 1.548 & 4.924 & 4.222 \\
\hline$(0,5)$ & $0.009^{* *}$ & 385 & 2.129 & 2.094 & 2.389 & $0.013^{* * *}$ & 238 & 2.969 & 3.539 & 3.443 \\
\hline$(0,3)$ & $0.005^{*}$ & 385 & 1.609 & 1.841 & 2.701 & $0.006^{*}$ & 238 & 1.484 & 2.111 & 1.556 \\
\hline$(0,1)$ & $0.006^{*}$ & 385 & 2.071 & 1.592 & 4.332 & 0.001 & 238 & 0.153 & 0.223 & 1.426 \\
\hline
\end{tabular}

Notes. Table 7 shows the results of event studies carried out on 623 listed European companies relating to the referendum vote (23 June 2016). 385 companies belong to UK export-oriented sectors, while 238 companies belong to UK import-oriented sectors. We measured the predicted normal bank returns using the market model. The CAR statistical significance is verified using three tests $\left(\mathrm{T}_{1}, \mathrm{~T}_{2}\right.$ and $\left.\mathrm{T}_{3}\right)$, reported in Equations (6), (7) and (9). ${ }^{*},{ }^{* *},{ }^{* * *}$ denote the statistical significance at $10 \%, 5 \%$ and $1 \%$, respectively (one-tailed test).

Focusing on UK companies (Table 6), our findings show negative and statistically significant mean CARs in the 
asymmetric event windows before the date for both export- and import-oriented industries. The explanation of these results considers that, in the day before 23 June 2016, there was high uncertainty on the referendum result. Informational efficiency requires that financial markets price political news before voting outcomes. If uncertainty about the result is not resolved as it draws near, investors are not able to assess the effect on the country's future and, for this reason, negative price changes should be expected, as suggested by Pantzalis et al. (2000), Brogaard and Detzel (2015), Krause et al. (2016) and Smales (2017). The UK press greatly stimulated this uncertainty. The analysis conducted by Levy et al. (2016) on the London editions of the nine national newspapers over the four months of the campaign show, in fact, that the UK press was divided into pro "remain" and pro "exit" camps, and the debate grew fiercer in the last week of the campaign. These results lead us to accept Hypothesis 2 in relation to the UK financial market.

On the contrary, import- and export-oriented UK companies reacted in a different way to the referendum vote. Specifically, the referendum outcome was almost uninformative for export-oriented industries, as CARs show statistically significant results only in the event window $(0,10)$. The reason could be that, in the days immediately following the referendum outcome, the market was probably confused about the possible effects of Brexit on UK exports. On the one hand, "remain" would have let Britain avoid exporter tariffs and red tape, in a period where about $45 \%$ of British exports went to the EU. On the other hand, "exit" could have led Britain to negotiate new relationships with the EU without being bound by European law, and to secure trade deals with other important international non-European partners (Wielechowski and Czech, 2016). These results confirm previous evidence found by Gros (2016), who demonstrates that, except for a weaker pound and lower UK interest rates, the referendum outcome did not make a clear impact on the UK financial market, probably because Brexit had not yet happened (Begg, 2016). Conversely, the referendum outcome was informative for import-oriented industries, as CARs show statistically significant results in the event windows after Day 0. In line with Oehler et al. (2017), these positive results indicate good political communication following the referendum outcome, which concentrated on the agreement that the UK and EU were to develop in order to negotiate a positive deal. This can justify also the positive impact of the referendum outcome on stock prices of other European companies for UK export- and import-oriented industries (Table 7). Our findings show, in fact, positive and statistically significant mean CARs (although magnitude is low) in all the investigated event windows (except the $(0,1)$ window) following Day 0. This means that other European financial markets as well as the UK one, priced "uncertainty" before Day 0 and, consequently, positively priced the "certain" information on the referendum outcome after its announcement. In addition, other European companies belonging to UK import-oriented industries (Table 7, Panel B) show negative and statistically significant mean CARs in the event windows $(-10,-1),(-5,-1)$ and $(-3,-1)$. As in the case of UK companies, these results can be explained considering that, in the day before the referendum vote, the outcome was uncertain and this uncertainty led to negative price changes, as suggested by Pantzalis et al. (2000), Brogaard and Detzel (2015), Krause et al. (2016) and Smales (2017).

The third event we investigate is the announcement of the election of Theresa May as Prime Minister, which took place on 11 July 2016. We report our findings on UK companies and other European firms in Tables 8 and 9, respectively.

Table 8. The election of Theresa May: the effect on UK companies

\begin{tabular}{|c|c|c|c|c|c|c|c|c|c|c|}
\hline \multirow[b]{2}{*}{ Event window } & \multicolumn{5}{|c|}{$\begin{array}{l}\text { Panel A) } \\
\text { Export-oriented industries }\end{array}$} & \multicolumn{5}{|c|}{$\begin{array}{l}\text { Panel B) } \\
\text { Import-oriented industries }\end{array}$} \\
\hline & Mean CAR & Number of firms & $\mathrm{T}_{1}$ & $\mathrm{~T}_{2}$ & $\mathrm{~T}_{3}$ & Mean CAR & Number of firms & $\mathrm{T}_{1}$ & $\mathrm{~T}_{2}$ & $\mathrm{~T}_{3}$ \\
\hline$(-10,-1)$ & $0.041^{* * *}$ & 90 & 3.027 & 2.463 & 3.795 & 0.016 & 81 & 0.835 & 2.708 & 2.778 \\
\hline$(-5,-1)$ & $0.027^{* *}$ & 90 & 2.858 & 2.078 & 3.162 & -0.008 & 81 & -0.555 & -0.225 & 0.333 \\
\hline$(-3,-1)$ & $0.019^{* * *}$ & 90 & 2.848 & 2.556 & 3.795 & -0.003 & 81 & -0.202 & 2.116 & -1.00 \\
\hline$(0,10)$ & $0.028^{* *}$ & 90 & 1.953 & 1.730 & 2.951 & $0.049^{* * *}$ & 81 & 3.304 & 2.725 & 3.222 \\
\hline$(0,5)$ & $0.030^{* *}$ & 90 & 3.022 & 1.783 & 3.373 & $0.040^{* * *}$ & 81 & 2.955 & 2.745 & 3.222 \\
\hline$(0,3)$ & $0.030^{* *}$ & 90 & 3.460 & 2.124 & 3.795 & $0.037^{* * *}$ & 81 & 3.761 & 2.523 & 3.444 \\
\hline$(0,1)$ & $0.032^{* *}$ & 90 & 3.960 & 2.053 & 4.216 & $0.032^{*}$ & 81 & 3.527 & 1.538 & 3.801 \\
\hline
\end{tabular}

Notes. Table 8 shows the results of event studies carried out on 171 listed UK companies related to the election of Theresa May as Prime Minister (11 July 2016). 90 companies belong to UK export-oriented sectors, while 81 companies belong to UK import-oriented sectors. We measured the predicted normal bank returns using the market model. The CAR statistical significance is verified using three tests $\left(\mathrm{T}_{1}\right.$, $\mathrm{T}_{2}$ and $\mathrm{T}_{3}$ ), reported in Equations (6), (7) and (9). ${ }^{*},{ }^{* *},{ }^{* * *}$ denote the statistical significance at $10 \%, 5 \%$ and $1 \%$, respectively (one-tailed test). 
Table 9. The election of Theresa May: the effect on non-UK companies

\begin{tabular}{lllllllllll}
\hline \multicolumn{1}{c}{$\begin{array}{l}\text { Panel } A \text { ) } \\
\text { Export }\end{array}$} & \multicolumn{10}{c}{$\begin{array}{l}\text { Panel B) } \\
\text { Import }\end{array}$} \\
\hline Event window & Mean CAR & Number of firms & $\mathrm{T}_{1}$ & $\mathrm{~T}_{2}$ & $\mathrm{~T}_{3}$ & Mean CAR & Number of firms & $\mathrm{T}_{1}$ & $\mathrm{~T}_{2}$ & $\mathrm{~T}_{3}$ \\
\hline$(-10,-1)$ & 0.005 & 386 & 0.818 & -0.246 & -0.305 & 0.008 & 239 & 0.743 & 5.244 & 4.334 \\
$(-5,-1)$ & -0.001 & 386 & -0.353 & 0.623 & 1.120 & 0.007 & 239 & 2.091 & 1.049 & 0.970 \\
$(-3,-1)$ & -0.001 & 386 & -0.197 & 0.997 & -2.443 & 0.003 & 239 & 1.109 & 1.136 & 0.194 \\
$(0,10)$ & $0.027^{* *}$ & 386 & 3.679 & 1.764 & 5.090 & $0.023^{* * *}$ & 239 & 3.798 & 2.611 & 3.558 \\
$(0,5)$ & $0.027^{* * *}$ & 386 & 4.952 & 2.560 & 5.395 & $0.017^{* *}$ & 239 & 3.365 & 2.387 & 2.135 \\
$(0,3)$ & $0.025^{* * *}$ & 386 & 5.012 & 2.827 & 5.802 & $0.015^{* *}$ & 239 & 3.068 & 1.773 & 1.945 \\
$(0,1)$ & $0.016^{*}$ & 386 & 4.679 & 1.570 & 5.657 & $0.007^{* *}$ & 239 & 1.701 & 1.780 & 2.022 \\
\hline
\end{tabular}

Notes. Table 9 shows the results of event studies carried out on 625 listed European companies related to the election of Theresa May as Prime Minister (11 July 2016). 386 companies belong to UK export-oriented sectors, while 239 companies belong to UK import-oriented sectors. We measured the predicted normal bank returns using the market model. The CAR statistical significance is verified using three tests $\left(\mathrm{T}_{1}, \mathrm{~T}_{2}\right.$ and $\mathrm{T}_{3}$ ), reported in Equations (6), (7) and (9). ${ }^{* * *},{ }^{* * *}$ denote the statistical significance at $10 \%, 5 \%$ and $1 \%$, respectively (one-tailed test).

Our findings show positive and statistically significant mean CARs in all the event windows following Day 0 , both for the UK and other European companies. In the case of UK firms (Table 8), all the event windows following Day 0 show positive statistically significant mean CARs ranging from $2.8 \%$ (in the event window $(0,10)$ for export-oriented industries, Table 8 , Panel A) to $4.9 \%$ (in the event window $(0,10)$ for import-oriented industries, Table 8, Panel B). In the case of other European firms, we again found positive and statistically significant results, although their magnitude is lower than in the previous subsample (Table 9). Accordingly, this considers that the election of Theresa May as Prime Minister was interpreted as "good news" by financial markets, both in the UK and in the other European countries. Mrs. May had, in fact, established a firm lead in the first round of voting, winning the support of more than half of the party's MPs, and she was perceived as a trustworthy and credible politician. On 11 July 2016, she immediately declared that UK would leave the European Union and there would be "no attempts to remain inside the EU", with no second referendum or "attempts to rejoin it by the backdoor", and that "together with the British people, she would build a better Britain." In this context, the election of Theresa May as Prime Minister allowed investors to assess immediately the effect on the country's future. As suggested by Pantzalis et al. (2000), Goodel and Vähämaa (2013), Brogaard and Detzel (2015) and Samles (2015, 2016), in this case positive price changes are not to be expected, as uncertainty about the policies to be implemented after the vote is resolved "ex ante".

\subsection{Econometric Results}

In order to investigate the determinants of significant CARs quantified in the three event dates related to Brexit, we run some cross-sectional regressions on the four subsamples.

First, we focus on 20 February 2016 (Table 10). We run some regressions on CARs estimated in the event windows showing the highest significance in the event study analysis. The magnitude of the coefficients is higher for sectorial variables than for firm-specific characteristics. This means CARs are affected more by industry than by the company fundamentals. Table 10 shows, in fact, that investor reaction is particularly evident in mining (for both UK and other EU import-oriented firms) and metallurgical industries (for both UK and other EU exporters). With regard to the company fundamentals, only size shows a positive and significant relationship with CARs of the export-oriented firms (both UK and Non-UK), which suggests that investor reaction may be stronger for larger companies. ROS appears to be negligible for European companies operating in UK import-oriented industries (NO UK import). Finally, focusing on UK import-oriented firms, investors seem to react more positively when companies show lower capitalization and higher liquidity.

Second, we tried to explain the CARs estimated around the referendum date. We detect the determinants of CARs calculated in the asymmetric event window $(-3,-1)$, i.e. the event window prior to the event showing the highest statistical significance (at $1 \%$ ), and $(0,5)$, i.e. the most statistically significant event window following Day 0 . We limited the analysis to the UK import-oriented firms, as they are the only companies presenting statistically significant CARs. Table 11 reports our results.

The role of firm fundamentals in determining investor reaction to the outcome of the referendum is modest. ROS has a very small coefficient in the case of UK import-oriented companies, thus suggesting that the profitability 
effect on CARs is small. Looking at size, its effect is different considering import and export-oriented firms. In fact, larger companies show higher abnormal returns after the referendum and lower negative abnormal returns in the period before Day 0. With regard to capitalization (E_TA) and liquidity (CURRENT_RATIO), their coefficients, although negative and statistically significant, are so small that a relevant explanation cannot be identified for the value of these firm-specific variables. Looking at the magnitude of coefficients, the industry has a greater significant effect on CARs than company characteristics. In particular, UK firms operating in the mining sector show higher positive CARs after the referendum vote. We also identify negative CARs before Day 0 for the metallurgical sector in UK export-oriented companies.

Our last analysis focuses on the announcement of the election of Theresa May as Prime Minister- We consider only the asymmetric event windows $(0,+3)$ - with the exception of the UK export firms, for which we also consider the statistically significant asymmetric event window $(-3,-1)$ - because it shows the highest significance in the event study analysis. The results are reported in Table 12. In the case of UK companies, firm-specific characteristics do not mainly contribute to explaining CARs, except for size for UK export-oriented firms and ROS in UK import-oriented firms, where, however, the magnitude of coefficient is low enough to be negligible. In other European countries too, larger firms show higher cumulative abnormal returns after the announcement of the new Prime Minister. Moreover, our results show that, in the case of other European firms operating in UK import-oriented industries, ROS and Equity on Total Assets are negatively related to the dependent variable. However, their coefficients are so low that the explanatory role of profitability and capitalization seem to be negligible. Finally, the sectorial effect appears significant only for UK export-oriented companies.

Table 10. Regression analysis: investor reaction to the referendum date announcement

\begin{tabular}{|c|c|c|c|c|c|c|c|c|}
\hline \multirow[b]{2}{*}{ VARIABLES } & \multicolumn{2}{|c|}{ UK IMPORT } & \multicolumn{2}{|c|}{ UK EXPORT } & \multicolumn{2}{|c|}{ NO UK IMPORT } & \multicolumn{2}{|c|}{ NO UK EXPORT } \\
\hline & $\operatorname{EW}(-3,-1)$ & $\operatorname{EW}(0,10)$ & $\operatorname{EW}(-3,-1)$ & $\operatorname{EW}(0,10)$ & $\operatorname{EW}(-3,-1)$ & $\operatorname{EW}(0,10)$ & $\operatorname{EW}(-3,-1)$ & $\operatorname{EW}(0,10)$ \\
\hline \multirow[t]{2}{*}{ Constant } & 0.007 & 0.050 & 0.021 & -0.223 & -0.025 & -0.098 & -0.028 & -0.051 \\
\hline & $(0.043)$ & $(0.125)$ & $(0.045)$ & $(0.139)$ & $(0.029)$ & $(0.074)$ & $(0.018)$ & $(0.043)$ \\
\hline \multirow[t]{2}{*}{ ROS } & $-4.68 \mathrm{e}-07$ & $6.79 \mathrm{e}-07$ & $-1.88 \mathrm{e}-07$ & $-2.08 \mathrm{e}-05$ & $-3.42 \mathrm{e}-05^{*}$ & $2.57 \mathrm{e}-05$ & $1.39 \mathrm{e}-07$ & $3.76 \mathrm{e}-06$ \\
\hline & $(6.62 \mathrm{e}-07)$ & $(1.90 \mathrm{e}-06)$ & $(5.86 \mathrm{e}-06)$ & $(1.78 \mathrm{e}-05)$ & $(2.05 \mathrm{e}-05)$ & $(5.23 \mathrm{e}-05)$ & $(1.71 \mathrm{e}-06)$ & $(3.99 \mathrm{e}-06)$ \\
\hline \multirow[t]{2}{*}{ SIZE } & 0.001 & 0.010 & -0.001 & $0.017 * *$ & 0.002 & 0.008 & $0.002^{* *}$ & $0.006^{* *}$ \\
\hline & $(0.002)$ & $(0.006)$ & $(0.003)$ & $(0.008)$ & $(0.002)$ & $(0.005)$ & $(0.001)$ & $(0.002)$ \\
\hline \multirow[t]{2}{*}{ E_TA } & -0.001 & $-0.002 * * *$ & -0.001 & $2.50 \mathrm{e}-05$ & $2.34 \mathrm{e}-05$ & -0.000 & 0.000 & -0.001 \\
\hline & $(0.000)$ & $(0.001)$ & $(0.000)$ & $(0.001)$ & $(5.66 \mathrm{e}-05)$ & $(0.000)$ & $(0.000)$ & $(0.000)$ \\
\hline \multirow[t]{2}{*}{ CURRENT } & 0.001 & $0.006^{* *}$ & 0.001 & -0.013 & 0.003 & 0.005 & -0.001 & 0.001 \\
\hline & $(0.000)$ & $(0.002)$ & $(0.003)$ & $(0.010)$ & $(0.003)$ & $(0.007)$ & $(0.001)$ & $(0.002)$ \\
\hline \multirow[t]{2}{*}{ FOOD } & -0.026 & -0.011 & - & - & -0.006 & -0.028 & - & - \\
\hline & $(0.020)$ & $(0.057)$ & & & $(0.011)$ & $(0.030)$ & & \\
\hline \multirow[t]{2}{*}{ MINING } & 0.018 & $0.105^{* *}$ & - & - & $-0.029^{*}$ & $0.070^{*}$ & - & - \\
\hline & $(0.014)$ & $(0.042)$ & & & $(0.015)$ & $(0.038)$ & & \\
\hline \multirow[t]{2}{*}{ VEHICLES } & - & - & -0.000 & 0.075 & - & - & 0.002 & 0.030 \\
\hline & & & $(0.029)$ & $(0.089)$ & & & $(0.012)$ & $(0.027)$ \\
\hline \multirow[t]{2}{*}{ CHEMICAL } & - & - & 0.001 & 0.117 & - & - & 0.004 & 0.040 \\
\hline & & & $(0.023)$ & $(0.070)$ & & & $(0.010)$ & $(0.025)$ \\
\hline \multirow[t]{2}{*}{ MACHINERY } & - & - & -0.003 & 0.099 & - & - & -0.001 & 0.019 \\
\hline & & & $(0.025)$ & $(0.077)$ & & & $(0.010)$ & $(0.023)$ \\
\hline \multirow[t]{2}{*}{ METAL } & - & - & $0.044^{*}$ & $0.182^{* *}$ & - & - & -0.002 & $0.101 * * *$ \\
\hline & & & $(0.023)$ & $(0.071)$ & & & $(0.011)$ & $(0.026)$ \\
\hline COUNTRY FE & - & - & - & - & YES & YES & YES & YES \\
\hline Observations & 67 & 67 & 80 & 79 & 234 & 234 & 349 & 349 \\
\hline Ad. R-squared & 0.110 & 0.306 & 0.135 & 0.182 & 0.093 & 0.128 & 0.046 & 0.150 \\
\hline
\end{tabular}

Table 10 shows the results of the regression model run on CARs estimated around the announcement of the referendum date $(20$ February 2016). The dependent variables are CARs quantified in the event windows showing the highest significance in the event study analysis both for subsamples of UK and EU companies. Independent variables are distinguished between firm-specific and sectorial variables. Firm-specific variables are the following: return on sales (ROS) as proxy of profitability, equity over total assets (E_TA) as measure of 
capitalization, the natural logarithm of total revenues (SIZE) as proxy of firm size and the liquidity ratio (CURRENT) are proxy of liquidity. In the second group we have a series of dummy variables for each industry: food, mining, vehicles, chemical, machinery and metal. COUNTRY FE is a series of dummy variables for each European country. ${ }^{*},{ }^{* *},{ }^{* * *}$ denote the statistical significance at $10 \%, 5 \%$ and $1 \%$ level, respectively.

Table 11. Regression analysis: investor reaction to the referendum result announcement

\begin{tabular}{|c|c|c|c|}
\hline & UK IMPORT & & UK EXPORT \\
\hline VARIABLES & $\operatorname{EW}(0 ; 5)$ & $\operatorname{EW}(-3 ;-1)$ & $\operatorname{EW}(-3 ;-1)$ \\
\hline \multirow[t]{2}{*}{ Constant } & -0.005 & 0.021 & $-0.082 * *$ \\
\hline & $(0.077)$ & $(0.039)$ & $(0.040)$ \\
\hline \multirow[t]{2}{*}{ ROS } & $-2.35 \mathrm{e}-06^{*}$ & $1.27 \mathrm{e}-06^{* *}$ & $1.83 \mathrm{e}-06$ \\
\hline & $(1.18 \mathrm{e}-06)$ & $(5.96 \mathrm{e}-07)$ & $(5.08 \mathrm{e}-06)$ \\
\hline \multirow[t]{2}{*}{ SIZE } & $0.009 * *$ & -0.003 & $0.005^{* *}$ \\
\hline & $(0.004)$ & $(0.002)$ & $(0.002)$ \\
\hline \multirow[t]{2}{*}{ E_TA } & $-0.001 * *$ & 0.001 & 0.0003 \\
\hline & $(0.001)$ & $(0.000)$ & $(0.000)$ \\
\hline \multirow[t]{2}{*}{ CURRENT } & 0.001 & $-0.002 * * *$ & 0.002 \\
\hline & $(0.002)$ & $(0.001)$ & $(0.003)$ \\
\hline \multirow[t]{2}{*}{ FOOD } & $5.56 \mathrm{e}-05$ & 0.004 & - \\
\hline & $(0.035)$ & $(0.018)$ & \\
\hline \multirow[t]{2}{*}{ MINING } & $0.057^{* *}$ & -0.021 & - \\
\hline & $(0.026)$ & $(0.013)$ & \\
\hline \multirow[t]{2}{*}{ VEHICLES } & - & - & -0.029 \\
\hline & & & $(0.026)$ \\
\hline \multirow[t]{2}{*}{ CHEMICAL } & & - & -0.003 \\
\hline & & & $(0.019)$ \\
\hline \multirow[t]{2}{*}{ MACHINERY } & - & - & -0.006 \\
\hline & & & $(0.021)$ \\
\hline \multirow[t]{2}{*}{ METAL } & - & - & $-0.048^{* *}$ \\
\hline & & & $(0.020)$ \\
\hline Observations & 67 & 67 & 78 \\
\hline Ad. R-squared & 0.268 & 0.245 & 0.227 \\
\hline
\end{tabular}

Table 11 shows the results of the regression model run on CARs estimated around the announcement of the referendum result (23 June 2016). The dependent variables are CARs quantified in the event windows showing the highest significance in the event study analysis both for subsamples of UK and EU companies. Independent variables are distinguished between firm-specific and sectorial variables. Firm-specific variables are the following: return on sales (ROS) as proxy of profitability, equity over total assets (E_TA) as measure of capitalization, the natural logarithm of total revenues (SIZE) as proxy of firm size and the liquidity ratio (CURRENT) are proxy of liquidity. In the second group we have a series of dummy variables for each industry: food, mining, vehicles, chemical, machinery and metal. COUNTRY FE is a series of dummy variables for each European country. ${ }^{*},{ }^{* *},{ }^{* * *}$ denote the statistical significance at $10 \%, 5 \%$ and $1 \%$ level, respectively. 
Table 12. Regression analysis: investor reaction to the appointment of Theresa May announcement

\begin{tabular}{|c|c|c|c|c|c|}
\hline & UK IMPORT & UK EXPORT & & NO UK IMPORT & NO UK EXPORT \\
\hline VARIABLES & $\operatorname{EW}(0 ;+3)$ & $\operatorname{EW}(0 ;+3)$ & $\operatorname{EW}(-; 3 ;-1)$ & $\mathrm{EW}(0 ;+3)$ & $\operatorname{EW}(0 ;+3)$ \\
\hline \multirow[t]{2}{*}{ Constant } & $0.111^{*}$ & -0.049 & -0.032 & -0.034 & $-0.076^{* * *}$ \\
\hline & $(0.065)$ & $(0.060)$ & $(0.043)$ & $(0.031)$ & $(0.027)$ \\
\hline \multirow[t]{2}{*}{ ROS } & $3.60 \mathrm{e}-06^{* * *}$ & $-3.36 \mathrm{E}-06$ & $-4.37 \mathrm{E}-06$ & $-4.79 \mathrm{e}-05^{* *}$ & $-1.15 \mathrm{E}-06$ \\
\hline & (9.97E-07) & (7.79E-06) & $(5.64 \mathrm{E}-06)$ & $(2.20 \mathrm{E}-05)$ & $(2.56 \mathrm{E}-06)$ \\
\hline \multirow[t]{2}{*}{ SIZE } & -0.004 & $0.006^{*}$ & 0.0013 & $0.004 *$ & $0.006^{* * *}$ \\
\hline & $(0.003)$ & $(0.004)$ & $(0.002)$ & $(0.002)$ & $(0.002)$ \\
\hline \multirow[t]{2}{*}{ E_TA } & -0.001 & 0.000 & -0.000 & $-0.0001 * * *$ & 0.001 \\
\hline & $(0.000)$ & $(0.000)$ & $(0.000)$ & (6.08E-05) & $(0.001)$ \\
\hline \multirow[t]{2}{*}{ CURRENT } & 0.001 & -0.004 & 0.001 & 0.002 & -0.001 \\
\hline & $(0.001)$ & $(0.004)$ & $(0.003)$ & $(0.003)$ & $(0.001)$ \\
\hline \multirow[t]{2}{*}{ FOOD } & -0.021 & - & - & -0.019 & - \\
\hline & $(0.030)$ & & & $(0.012)$ & \\
\hline \multirow[t]{2}{*}{ MINING } & 0.031 & - & - & -0.022 & - \\
\hline & $(0.022)$ & & & $(0.016)$ & \\
\hline \multirow[t]{2}{*}{ VEHICLES } & - & -0.006 & $0.048^{*}$ & - & 0.012 \\
\hline & & $(0.039)$ & $(0.028)$ & & $(0.017)$ \\
\hline \multirow[t]{2}{*}{ CHEMICAL } & - & -0.009 & $0.048 * *$ & - & 0.001 \\
\hline & & $(0.030)$ & $(0.022)$ & & $(0.016)$ \\
\hline \multirow[t]{2}{*}{ MACHINERY } & - & $2.35 \mathrm{E}-05$ & $0.053 * *$ & - & 0.005 \\
\hline & & $(0.033)$ & $(0.024)$ & & $(0.015)$ \\
\hline \multirow[t]{2}{*}{ METAL } & - & 0.024 & $0.057 * *$ & - & 0.018 \\
\hline & & $(0.031)$ & $(0.022)$ & & $(0.016)$ \\
\hline COUNTRY FE & - & & & yes & Yes \\
\hline Observations & 67 & 80 & 80 & 233 & 349 \\
\hline Ad. R-squared & 0.227 & 0.108 & 0.119 & 0.077 & 0.102 \\
\hline
\end{tabular}

Table 12 shows the results of the regression model run on CARs estimated around the announcement of the appointment of Theresa May as Prime Minister (11 July 2016). The dependent variables are CARs quantified in the event windows showing the highest significance in the event study analysis both for subsamples of UK and EU companies. Independent variables are distinguished between firm-specific and sectorial variables. Firm-specific variables are the following: return on sales (ROS) as proxy of profitability, equity over total assets (E_TA) as measure of capitalization, the natural logarithm of total revenues (SIZE) as proxy of firm size and the liquidity ratio (CURRENT) are proxy of liquidity. In the second group we have a series of dummy variables for each industry: food, mining, vehicles, chemical, machinery and metal. COUNTRY FE is a series of dummy variables for each European country. ${ }^{*},{ }^{* *},{ }^{* * *}$ denote the statistical significance at $10 \%, 5 \%$ and $1 \%$ level, respectively.

Our results show overall that investor reaction to different events related to Brexit depends more on industry factors than on firm-specific characteristics, both for UK and EU companies. These results lead us to accept Hypothesis 4 both in relation to the UK and other-European countries' financial markets. This confirms previous findings by Jacowicz et al. (2017), who show a very low explanatory power of firm fundamentals. The only exception is company size, which also positively affects investor reaction in our research. These results suggest, in the events related to Brexit that we investigated, investors reacted uniformly, firm characteristics are less important, and industry factors prevail.

\section{Additional Analysis and Robustness Checks}

\subsection{Additional Analysis}

In order to verify consistency between the results of the event studies and mass media sentiment, we performed a text analysis based on LexisNexis articles referring to Brexit. We carried out this analysis in three steps. First, we selected relevant articles using the following research criteria. The headline of the news selected must contain the word "Brexit" and one of the two words: "economic" or "economy. We extracted news articles from the LexisNexis database with the category "Major World Publications" (in English) and covered a period ranging from 10 days before to 10 days after each event referring to Brexit. 
Second, for each piece of news, the publication date was extracted; we considered the exact date the news has been published and not the "load-date" provided by the database, LexisNexis. This is because, in some cases, we found a lag between the actual publication date of articles and the date the news was uploaded to the database.

Third, in order to study the content of the news, we used the text analysis technique (Stone, Dunphy, Smith \& Ogilvie, 1966) through the Linguistic Inquiry and Word Count (LIWC) approach. It is a textual analysis program, allocating words to psychologically meaningful categories (Pennebaker, Chung, Ireland \& Booth, 2007; Pennebaker and King, 1999; Pennebaker and Francis, 1996; Tausczik and Pennebaker, 2010). In this analysis, we considered the following:

- $\quad$ LIWC Category 126 - posemo (examples include the following words: positive, nice, advantage);

- $\quad$ LIWC Category 127 - negemo (examples include the following words: negative, hurt, fear).

After collecting and counting the number of positive and negative words in each news piece, we measured the PMN indicator (Positive minus Negative). This indicator assesses the degree to which each news piece is oriented, i.e. towards positive and negative emotions, and is calculated as: $(\mathrm{P}-\mathrm{N}) / \mathrm{W}$, where $\mathrm{P}, \mathrm{N}$ and $\mathrm{W}$, respectively, are the number of positive, negative and total words of articles referring to the announcements of the referendum date (20 February 2016), the referendum result (23 June 2016) and the election of Theresa May as Prime Minister (11 July 2016), considering the event windows $(0,10)$ and $(-10,-1)$.

The results of the analysis of mass media content based on LexisNexis articles referring to Brexit are illustrated in Table 13 below.

Table 13. Mass media sentiment related to Brexit events

\begin{tabular}{lll}
\hline Event & Event window & PMN \\
\hline \multirow{2}{*}{ Announcement of the referendum date (20/02/2016) } & $(0,10)$ & $-0.62 \%$ \\
& $(-10,-1)$ & $0.58 \%$ \\
Referendum result (23/06/2016) & $(0,10)$ & $0.15 \%$ \\
& $(-10,-1)$ & $-0.12 \%$ \\
Election of Theresa May as Prime Minister $\mathbf{( 1 1 / 0 7 / 2 0 1 6 )}$ & $(0,10)$ & $0.10 \%$ \\
\hline
\end{tabular}

Notes. Table 13 shows mass media sentiment related to Brexit events. The PMN (Positive minus Negative) index is calculated as: $(\mathrm{P}-\mathrm{N}) / \mathrm{W}$, where $\mathrm{P}, \mathrm{N}$ and $\mathrm{W}$ are, respectively, the number of positive, negative and total words, of the articles referred to the announcements of the referendum date (20 February 2016), the referendum result (23 June 2016) and the election of Theresa May as Prime Minister (11 July 2016) considering the event windows $(0,10)$ and $(-10,-1)$.

During the whole Brexit campaign, there was more coverage of "Leave" arguments; as shown by Deacon, Downey, Harmer E, et al. (2016), in this period the circulation of 'out' messaging newspapers outweighed 'in' by $80 \%$ to $20 \%$. Our analysis seems to confirm this fact. The 3 main sources of news around the Brexit events (containing the word "Brexit" and one of the two words "economic" or "economy" in the headline) were all UK newspapers: The Guardian (72 articles), The Independent (51 articles), and The Mirror (22 articles).

Referring to the announcement of the referendum date, our findings reported in Section 4.1 show positive and statistically significant mean CARs in almost all the investigated event windows. In this context, mass media sentiment about Brexit before the event is very positive $(0.58 \%)$, but it reverses in the subsequent period, where it becomes largely negative $(-0.62 \%)$. The findings of the text analysis support our event study results registered in the event windows prior to February $20^{\text {th }}$, as the number of positive news is widely higher than the number of negative ones. In this context, the "remain" result probably allowed investors to assess immediately the effect on the country's future. As suggested by Pantzalis et al. (2000), in this case positive price changes should be expected given that uncertainty about the policies to be implemented after the vote is resolved "ex ante".

When it comes to the referendum day (23/06/2016), both import and export-oriented UK companies register negative and statistically significant mean CARs in the event windows prior to Day 0 . This means that there was probably high uncertainty on the referendum result. Evidence of our text analysis supports this idea. News published in the ten days before June 23rd are, in fact, mainly negative, but the difference between negative and positive information is small, as the PMN indicator is equal to $-0.12 \%$

Finally, regarding the election of Theresa May as Prime Minister (11/07/2016), our findings show positive and statistically significant mean CARs in all the event windows prior to and after Day 0. In this context, the PMN 
indicator is slightly positive both before $(0.19 \%)$ and after $(0.10 \%)$ the event. The results of our text analysis, thus, support the evidence shown by the event study analysis; mass media sentiment referring to news published in the ten days prior to and after July 11 th is, in fact, always positive.

\subsection{Robustness Checks}

To test the robustness of our main analysis, we run our regression model on significant CARs of other event windows examined in the event study analysis.

With regard to the referendum result, these findings, reported in Table 14, generally confirm previous results. Investor reaction is, in fact, stronger in the case of the larger and more liquid companies. Moreover, we identify a negative relationship between cumulative abnormal returns estimated after the referendum date announcement and firm capitalization, as shown in our main analysis. Also in line with previous results, the coefficients of firm-specific characteristics are very low and may be considered negligible. On the other hand, although the coefficients of industry dummy variables are not always significant, their magnitude is important.

Results relating to the referendum date announcement, reported in Table 15, also substantially confirm our main findings. In fact, the mining sector shows the highest significant coefficient in the case of UK import-oriented firms, while the metallurgical industry is significant in case of UK export-oriented companies. Finally, the robustness checks reported in Table 16 confirm previous findings on the announcement of Theresa May as Prime Minister.

Table 14. Robustness checks: investor reaction to the referendum result announcement

\begin{tabular}{|c|c|c|c|c|}
\hline & UK IMPORT & & & UK EXPORT \\
\hline & $\operatorname{EW}(0 ;+1)$ & $\operatorname{EW}(0 ;+3)$ & $\mathrm{EW}(-5 ;-1)$ & $\operatorname{EW}(-5 ;-1)$ \\
\hline \multirow[t]{2}{*}{ Constant } & -0.063 & -0.086 & 0.002 & -0.038 \\
\hline & $(0.053)$ & $(0.066)$ & $(0.044)$ & $(0.044)$ \\
\hline \multirow[t]{2}{*}{ ROS } & $-1.85 \mathrm{e}-06^{* *}$ & $-2.47 e-06^{* *}$ & $9.09 \mathrm{e}-07$ & $6.93 \mathrm{e}-06$ \\
\hline & $(8.11 \mathrm{e}-07)$ & $(1.00 \mathrm{e}-06)$ & $(6.78 \mathrm{e}-07)$ & $(5.67 \mathrm{e}-06)$ \\
\hline \multirow[t]{2}{*}{ SIZE } & $0.009 * * *$ & $0.011 * * *$ & -0.001 & 0.004 \\
\hline & $(0.002)$ & $(0.003)$ & $(0.002)$ & $(0.003)$ \\
\hline \multirow[t]{2}{*}{ E_TA } & $-0.001 *$ & $-0.001 * *$ & 0.000 & $-9.30 e-05$ \\
\hline & $(0.000)$ & $(0.000)$ & $(0.001)$ & $(0.000)$ \\
\hline \multirow[t]{2}{*}{ CURRENT } & 0.001 & 0.001 & $0.002 * * *$ & 0.001 \\
\hline & $(0.001)$ & $(0.001)$ & $(0.001)$ & $(0.003)$ \\
\hline \multirow[t]{2}{*}{ FOOD } & -0.000 & -0.002 & -0.006 & - \\
\hline & $(0.024)$ & $(0.030)$ & $(0.020)$ & \\
\hline \multirow[t]{2}{*}{ MINING } & $0.040 * *$ & $0.063 * * *$ & $-0.035^{* *}$ & - \\
\hline & $(0.018)$ & $(0.022)$ & $(0.015)$ & \\
\hline \multirow[t]{2}{*}{ VEHICLES } & - & - & - & -0.031 \\
\hline & & & & $(0.028)$ \\
\hline \multirow[t]{2}{*}{ CHEMICAL } & - & - & - & -0.030 \\
\hline & & & & $(0.022)$ \\
\hline \multirow[t]{2}{*}{ MACHINERY } & - & - & - & -0.032 \\
\hline & & & & $(0.024)$ \\
\hline \multirow[t]{2}{*}{ METALL } & - & - & - & $-0.060 * * *$ \\
\hline & & & & $(0.022)$ \\
\hline Observations & 67 & 67 & 67 & 79 \\
\hline Ad. R-squared & 0.296 & 0.335 & 0.258 & 0.192 \\
\hline
\end{tabular}

Table 14 shows the results of the robustness check on CARs estimated around the announcement of the referendum result (23 June 2016). The dependent variables are CARs quantified in the event windows showing significance in the event study analysis both for subsamples of UK and EU companies. Independent variables are distinguished between firm-specific and sectorial variables. Firm-specific variables are the following: return on sales (ROS) as proxy of profitability, equity over total assets (E_TA) as measure of capitalization, the natural logarithm of total revenues (SIZE) as proxy of firm size and the liquidity ratio (CURRENT) are proxy of 
liquidity. In the second group we have a series of dummy variables for each industry: food, mining, vehicles, chemical, machinery and metal. COUNTRY FE is a series of dummy variables for each European country. *, **, $* * *$ denote the statistical significance at $10 \%, 5 \%$ and $1 \%$ level, respectively.

Table 15. Robustness checks: investor reaction to the referendum date announcement

\begin{tabular}{|c|c|c|c|c|c|c|c|c|c|c|c|c|c|c|c|c|c|c|}
\hline \multirow[b]{2}{*}{ VARIABLES } & \multicolumn{5}{|c|}{ UK IMPORT } & \multicolumn{5}{|c|}{ UK EXPORT } & \multicolumn{4}{|c|}{ NO UK IMPORT } & \multicolumn{4}{|c|}{ NO UK EXPORT } \\
\hline & $(0,+1)$ & $(0,+3)$ & $(0,+5)$ & $(-5,-1)$ & $(-10,-1)$ & $(0,+1)$ & $(0,+3)$ & $(0,+5)$ & $(-5,-1)$ & $(-10,-1)$ & $(0,+1)$ & $(0,+3)$ & $(0,+5)$ & $(-5,-1)$ & $(0,+1)$ & $(0,+3)$ & $(0,+5)$ & $(-5,-1)$ \\
\hline \multirow[t]{2}{*}{ Constant } & -0.031 & 0.032 & 0.005 & 0.047 & $-0.134^{*}$ & -0.029 & -0.056 & -0.121 & -0.072 & -0.032 & $-0.061^{* * *}$ & $-0.066^{*}$ & $-0.159 * * *$ & -0.012 & $-0.065 * *$ & $-0.060^{* * *}$ & -0.052 & -0.002 \\
\hline & $(0.067)$ & $(0.076)$ & $(0.088)$ & $(0.052)$ & $(0.076)$ & $(0.051)$ & $(0.0651)$ & $(0.0763)$ & $(0.052)$ & $(0.087)$ & $(0.030)$ & $(0.037)$ & $(0.046)$ & $(0.039)$ & $(0.025)$ & $(0.027)$ & $(0.033)$ & $(0.024)$ \\
\hline \multirow[t]{2}{*}{ ROS } & $-4.73 \mathrm{e}-07$ & $5.01 \mathrm{e}-07$ & $3.46 \mathrm{c}-07$ & $-1.41 \mathrm{e}-07$ & $-1.03 \mathrm{e}-06$ & $-5.50 \mathrm{e}-07$ & $-2.48 \mathrm{c}-06$ & $-7.01 \mathrm{e}-06$ & $-2.47 \mathrm{e}-06$ & $-5.52 \mathrm{e}-06$ & $2.86 \mathrm{e}-05$ & $2.91 \mathrm{e}-05$ & $1.82 \mathrm{e}-05$ & $-6.72 \mathrm{e}-06$ & $-2.14 \mathrm{e}-07$ & $5.94 \mathrm{e}-07$ & $1.82 \mathrm{e}-06$ & $1.57 \mathrm{e}-06$ \\
\hline & $(1.01 \mathrm{e}-06)$ & $(1.15 \mathrm{e}-06)$ & $(1.34 \mathrm{e}-06)$ & $(7.96 \mathrm{e}-07)$ & $(1.16 \mathrm{c}-06)$ & $(6.62 \mathrm{e}-06)$ & $(8.37 \mathrm{e}-06)$ & $(9.82 \mathrm{e}-06)$ & $(6.76 \mathrm{e}-06)$ & $(1.12 \mathrm{e}-05)$ & $(2.08 \mathrm{e}-05)$ & $(2.53 \mathrm{e}-05)$ & $(3.22 \mathrm{e}-05)$ & $(2.75 \mathrm{e}-05)$ & $(2.37 \mathrm{e}-06)$ & $(2.52 \mathrm{e}-06)$ & $(3.05 \mathrm{e}-06)$ & $(2.25 \mathrm{e}-06)$ \\
\hline \multirow[t]{2}{*}{ SIZE } & $0.008^{* * *}$ & 0.00293 & 0.006 & 0.001 & $0.010^{* *}$ & 0.003 & 0.005 & $0.009 * *$ & $0.006^{* *}$ & 0.007 & $0.004^{* * *}$ & $0.005^{*}$ & $0.010^{* * *}$ & 0.003 & $0.005^{* * *}$ & $0.004^{* * * *}$ & $0.005^{* * *}$ & 0.001 \\
\hline & $(0.003)$ & $(0.004)$ & $(0.004)$ & $(0.002)$ & $(0.004)$ & $(0.003)$ & $(0.003)$ & $(0.004)$ & $(0.003)$ & $(0.005)$ & $(0.002)$ & $(0.002)$ & $(0.003)$ & $(0.002)$ & $(0.001)$ & $(0.001)$ & $(0.002)$ & $(0.001)$ \\
\hline \multirow[t]{2}{*}{ E_TA } & $-0.001^{* *}$ & $-0.001^{* * *}$ & $-0.001^{* *}$ & -0.001 & $7.28 \mathrm{c}-05$ & $0.0005^{* * *}$ & 0.000 & $6.42 \mathrm{e}-05$ & 0.001 & $-0.001^{* * * *}$ & $-0.001^{* *}$ & $-0.001^{* *}$ & $-9.22 \mathrm{e}-05$ & $0.0001^{* * * *}$ & -0.001 & -0.001 & $-7.24 \mathrm{e}-05$ & $5.84 \mathrm{c}-05$ \\
\hline & $(0.000)$ & $(0.000)$ & $(0.000)$ & $(0.000)$ & $(0.000)$ & $(0.000)$ & $(0.000)$ & $(0.000)$ & $(0.000)$ & $(0.000)$ & $(5.75 \mathrm{e}-05)$ & $(6.99 \mathrm{e}-05)$ & $(8.92 \mathrm{e}-05)$ & $(7.60 \mathrm{e}-05)$ & $(0.000)$ & $(0.000)$ & $(0.000)$ & $(0.000)$ \\
\hline \multirow[t]{2}{*}{ CURRENT } & $0.003^{* * *}$ & $0.003^{* *}$ & $0.005^{* *}$ & 0.000 & $-7.17 \mathrm{e}-06$ & $-0.007 *$ & -0.00433 & -0.004 & 0.000 & 0.000 & 0.002 & 0.001 & $0.007^{*}$ & -0.000 & 0.001 & 0.001 & 0.001 & -0.001 \\
\hline & $(0.001)$ & $(0.001)$ & $(0.001)$ & $(0.001)$ & $(0.001)$ & $(0.004)$ & $(0.004)$ & $(0.005)$ & $(0.003)$ & $(0.006)$ & $(0.002)$ & $(0.003)$ & $(0.004)$ & $(0.003)$ & $(0.001)$ & $(0.001)$ & $(0.001)$ & $(0.001)$ \\
\hline \multirow[t]{2}{*}{ FOOD } & 0.026 & 0.031 & 0.026 & $-0.049^{* *}$ & -0.033 & - & - & . & - & - & -0.008 & -0.010 & -0.014 & -0.004 & - & - & - & - \\
\hline & $(0.032)$ & $(0.036)$ & $(0.042)$ & $(0.024)$ & $(0.035)$ & & & & & & $(0.011)$ & $(0.014)$ & $(0.018)$ & $(0.015)$ & & & & \\
\hline \multirow[t]{2}{*}{ MINING } & 0.031 & 0.029 & 0.021 & 0.014 & $0.055^{* *}$ & - & - & & - & - & 0.002 & -0.006 & 0.005 & $-0.054 * * *$ & - & - & - & - \\
\hline & $(0.023)$ & $(0.025)$ & $(0.029)$ & $(0.017)$ & $(0.025)$ & & & & & & $(0.015)$ & $(0.018)$ & $(0.023)$ & $(0.020)$ & & & & \\
\hline \multirow[t]{2}{*}{ VEHICLES } & - & - & - & - & - & -0.016 & -0.0042 & 0.007 & 0.014 & 0.002 & - & - & . & - & 0.005 & 0.024 & 0.013 & 0.009 \\
\hline & & & & & & $(0.033)$ & $(0.041)$ & $(0.049)$ & $(0.033)$ & $(0.056)$ & & & & & $(0.016)$ & $(0.017)$ & $(0.021)$ & $(0.015)$ \\
\hline \multirow[t]{2}{*}{ CHEMICAL } & - & . & - & - & . & 0.006 & 0.028 & 0.051 & -0.002 & -0.001 & . & - & . & - & 0.023 & $0.040^{* * *}$ & 0.018 & -0.001 \\
\hline & & & & & & $(0.026)$ & $(0.033)$ & $(0.038)$ & $(0.026)$ & $(0.044)$ & & & & & $(0.014)$ & $(0.015)$ & $(0.019)$ & $(0.014)$ \\
\hline \multirow[t]{2}{*}{ MACHINERY } & - & . & - & & . & 0.003 & 0.010 & 0.015 & -0.010 & -0.029 & - & - & - & - & 0.017 & $0.031^{* * *}$ & 0.002 & 0.002 \\
\hline & & & & & & $(0.028)$ & $(0.036)$ & $(0.042)$ & $(0.029)$ & $(0.048)$ & & & & & $(0.014)$ & $(0.015)$ & $(0.018)$ & $(0.013)$ \\
\hline \multirow[t]{2}{*}{ METALL } & - & . & - & . & . & -0.023 & -0.001 & 0.015 & -0.009 & $0.141^{* * * *}$ & . & . & . & - & $0.026^{*}$ & $0.044 * * *$ & $0.049 * *$ & -0.002 \\
\hline & & & & & & $(0.026)$ & $(0.033)$ & $(0.039)$ & $(0.027)$ & $(0.045)$ & & & & & $(0.015)$ & $(0.016)$ & $(0.020)$ & $(0.014)$ \\
\hline COUNTRY FE & - & . & - & - & - & & & & & & YES & YES & YES & YES & YES & YES & YES & YES \\
\hline Observations & 63 & 65 & 66 & 67 & 67 & 78 & 78 & 79 & 80 & 80 & 232 & 232 & 234 & 234 & 348 & 348 & 349 & 349 \\
\hline Ad. R-squared & 0.276 & 0.164 & 0.194 & 0.127 & 0.180 & 0.135 & 0.071 & 0.109 & 0.079 & 0.405 & 0.154 & 0.165 & 0.156 & 0.142 & 0.144 & 0.079 & 0.131 & 0.052 \\
\hline
\end{tabular}

Table 15 shows the results of the robustness check on CARs estimated around the announcement of the referendum date (20 February 2016). The dependent variables are CARs quantified in the event windows showing significance in the event study analysis both for subsamples of UK and EU companies. Independent variables are distinguished between firm-specific and sectorial variables. Firm-specific variables are the following: return on sales (ROS) as proxy of profitability, equity over total assets (E_TA) as measure of capitalization, the natural logarithm of total revenues (SIZE) as proxy of firm size and the liquidity ratio (CURRENT) are proxy of liquidity. In the second group we have a series of dummy variables for each industry: food, mining, vehicles, chemical, machinery and metal. COUNTRY FE is a series of dummy variables for each European country. $* * *, * * *$ denote the statistical significance at $10 \%, 5 \%$ and $1 \%$ level, respectively. 
Table 16. Robustness checks: investor reaction to the appointment of Theresa May announcement

\begin{tabular}{|c|c|c|c|c|c|c|c|c|c|c|c|c|c|c|}
\hline \multirow[b]{2}{*}{ VARIABLES } & \multicolumn{3}{|l|}{ UK IMPORT } & \multicolumn{5}{|c|}{ UK EXPORT } & \multicolumn{3}{|c|}{ NO UK IMPORT } & \multicolumn{3}{|c|}{ NO UK EXPORT } \\
\hline & $(0,+1)$ & $(0,+5)$ & $(0,+10)$ & $(0,+1)$ & $(0,+5)$ & $(0,+10)$ & $(-5,-1)$ & $(-10,-1)$ & $(0,+1)$ & $(0,+5)$ & $(0,+10)$ & $(0,+1)$ & $(0,+5)$ & $(0,+10)$ \\
\hline \multirow[t]{2}{*}{ Constant } & 0.099 & $0.191^{* *}$ & $0.271^{* *}$ & -0.028 & -0.059 & -0.124 & -0.056 & -0.141 & $-0.098 * * *$ & $-0.097 * * *$ & $-0.076^{*}$ & $-0.070 * * *$ & $-0.074 * *$ & $-0.157 * * *$ \\
\hline & $(0.063)$ & $(0.089)$ & $(0.104)$ & $(0.051)$ & $(0.068)$ & $(0.104)$ & $(0.065)$ & $(0.096)$ & $(0.025)$ & $(0.033)$ & $(0.040)$ & $(0.020)$ & $(0.036)$ & $(0.050)$ \\
\hline \multirow[t]{2}{*}{ ROS } & $2.92 \mathrm{e}-06 * * *$ & $4.88 \mathrm{e}-06 * * *$ & $2.08 \mathrm{e}-06$ & $-2.87 \mathrm{e}-06$ & $-2.23 \mathrm{e}-06$ & $-6.74 \mathrm{e}-06$ & $-4.64 \mathrm{e}-06$ & $-1.51 \mathrm{e}-05$ & $-0.0001 * * *$ & $-6.60 \mathrm{e}-05 * * *$ & $-8.16 \mathrm{e}-05 * * *$ & $-8.98 \mathrm{e}-07$ & $2.35 \mathrm{e}-06$ & $-1.25 \mathrm{e}-06$ \\
\hline & $(9.66 \mathrm{e}-07)$ & $(1.35 \mathrm{e}-06)$ & $(1.57 \mathrm{e}-06)$ & $(6.61 \mathrm{e}-06)$ & $(8.79 \mathrm{e}-06)$ & $(1.34 \mathrm{e}-05)$ & $(8.45 \mathrm{e}-06)$ & $(1.25 \mathrm{e}-05)$ & $(1.78 \mathrm{e}-05)$ & $(2.37 \mathrm{e}-05)$ & $(2.82 \mathrm{e}-05)$ & $(1.93 \mathrm{e}-06)$ & $(3.38 \mathrm{e}-06)$ & $(4.68 \mathrm{e}-06)$ \\
\hline \multirow[t]{2}{*}{ SIZE } & -0.003 & $-0.009 *$ & $-0.011^{* *}$ & 0.004 & 0.006 & $0.012^{*}$ & 0.001 & 0.009 & $0.006 * * *$ & $0.006 * * *$ & $0.007 * *$ & $0.005^{* * *}$ & $0.007 * * *$ & $0.011^{* * *}$ \\
\hline & $(0.003)$ & $(0.004)$ & $(0.005)$ & $(0.003)$ & $(0.004)$ & $(0.006)$ & $(0.004)$ & $(0.005)$ & $(0.001)$ & $(0.002)$ & $(0.002)$ & $(0.001)$ & $(0.002)$ & $(0.003)$ \\
\hline \multirow[t]{2}{*}{ E_TA } & -0.000 & -0.000 & -0.001 & 0.000 & 0.000 & 0.000 & -0.000 & -0.000 & $-9.62 \mathrm{e}-05^{*}$ & $2.49 \mathrm{e}-05$ & $-0.0001^{*}$ & $0.0002^{*}$ & $-1.72 \mathrm{e}-05$ & $0.001 * *$ \\
\hline & $(0.000)$ & $(0.001)$ & $(0.001)$ & $(0.000)$ & $(0.000)$ & $(0.001)$ & $(0.000)$ & $(0.001)$ & $(4.90 \mathrm{e}-05)$ & $(6.56 \mathrm{e}-05)$ & $(7.81 \mathrm{e}-05)$ & $(0.000)$ & $(0.000)$ & $(0.0003)$ \\
\hline \multirow[t]{2}{*}{ CURRENT } & 0.001 & 0.000 & -0.001 & -0.003 & $-0.008^{*}$ & -0.003 & 0.001 & -0.003 & $0.005^{* *}$ & 0.005 & 0.000 & -0.001 & -0.001 & -0.003 \\
\hline & $(0.001)$ & $(0.001)$ & $(0.002)$ & $(0.003)$ & $(0.005)$ & $(0.007)$ & $(0.004)$ & $(0.007)$ & $(0.002)$ & $(0.003)$ & $(0.003)$ & $(0.000)$ & $(0.001)$ & $(0.002)$ \\
\hline \multirow[t]{2}{*}{ FOOD } & -0.003 & -0.024 & -0.065 & - & - & - & - & - & -0.004 & $-0.033^{* *}$ & $-0.038^{* *}$ & - & - & - \\
\hline & $(0.029)$ & $(0.041)$ & $(0.048)$ & & & & & & $(0.010)$ & $(0.013)$ & $(0.016)$ & & & \\
\hline \multirow[t]{2}{*}{ MINING } & 0.028 & 0.009 & -0.039 & - & - & - & - & - & -0.014 & $-0.042^{* *}$ & $-0.052^{* *}$ & - & - & - \\
\hline & $(0.021)$ & $(0.030)$ & $(0.035)$ & & & & & & $(0.013)$ & $(0.017)$ & $(0.020)$ & & & \\
\hline \multirow[t]{2}{*}{ VEHICLES } & - & - & - & -0.003 & -0.002 & -0.011 & 0.064 & 0.048 & - & - & - & 0.010 & 0.027 & 0.026 \\
\hline & & & & $(0.033)$ & $(0.044)$ & $(0.067)$ & $(0.042)$ & $(0.062)$ & & & & $(0.013)$ & $(0.023)$ & $(0.032)$ \\
\hline \multirow[t]{2}{*}{ CHEMICAL } & - & - & - & -0.003 & $5.41 \mathrm{e}-05$ & 0.007 & $0.072 * *$ & 0.069 & - & - & - & -0.008 & 0.013 & 0.005 \\
\hline & & & & $(0.026)$ & $(0.034)$ & $(0.053)$ & $(0.033)$ & $(0.049)$ & & & & $(0.012)$ & $(0.021)$ & $(0.029)$ \\
\hline \multirow[t]{2}{*}{ MACHINERY } & - & - & - & -0.003 & -0.003 & 0.009 & $0.067^{*}$ & 0.054 & - & - & - & -0.001 & 0.016 & 0.005 \\
\hline & & & & $(0.028)$ & $(0.038)$ & $(0.058)$ & $(0.036)$ & $(0.054)$ & & & & $(0.011)$ & $(0.020)$ & $(0.027)$ \\
\hline \multirow[t]{2}{*}{ METALL } & - & - & - & 0.020 & 0.016 & -0.032 & $0.136 * * *$ & $0.176 * * *$ & - & - & - & 0.011 & $0.039 *$ & 0.036 \\
\hline & & & & $(0.026)$ & $(0.035)$ & $(0.053)$ & $(0.034)$ & $(0.050)$ & & & & $(0.012)$ & $(0.0223)$ & $(0.030)$ \\
\hline COUNTRY FE & - & - & - & - & - & - & - & - & YES & YES & YES & YES & YES & YES \\
\hline Observations & 66 & 67 & 67 & 80 & 80 & 80 & 80 & 80 & 230 & 234 & 234 & 348 & 349 & 349 \\
\hline Ad. R-squared & 0.166 & 0.194 & 0.106 & 0.088 & 0.108 & 0.077 & 0.213 & 0.246 & 0.194 & 0.124 & 0.139 & 0.110 & 0.104 & 0.093 \\
\hline
\end{tabular}

Table 16 shows the results of the robustness check on CARs estimated around the announcement of the appointment of Theresa May as Prime Minister (11 July 2016). The dependent variables are CARs quantified in the event windows showing significance in the event study analysis both for subsamples of UK and EU companies. Independent variables are distinguished between firm-specific and sectorial variables. Firm-specific variables are the following: return on sales (ROS) as proxy of profitability, equity over total assets (E_TA) as measure of capitalization, the natural logarithm of total revenues (SIZE) as proxy of firm size and the liquidity ratio (CURRENT) are proxy of liquidity. In the second group we have a series of dummy variables for each industry: food, mining, vehicles, chemical, machinery and metal. COUNTRY FE is a series of dummy variables for each European country. $* * *, * * *$ denote the statistical significance at $10 \%, 5 \%$ and $1 \%$ level, respectively.

\section{Discussion and Conclusions}

The European political landscape is currently being shaken up by several unprecedented events that threaten the future of the European Union. Political uncertainty heavily affects market prices and increases capital market volatility.

In this context, our research tested market reaction to the most outstanding episode of the last few years, i.e. Brexit. We considered several events surrounding the 2016 British referendum, from Cameron's announcement to the election of Theresa May as Prime Minister, which opened up a possible new period for political stability. We focused on UK and other European import- and export-oriented listed companies. Through event studies, we assessed that markets positively priced the referendum date announcement, which shows that the "remain" outcome was considered highly likely and, thus, no political uncertainty was expected. On the other hand, we found negative CARs before 23 June 2016, due to the high level of uncertainty on the referendum result. This could have been driven by the UK press, which was divided into pro "remain" and pro "exit" camps, which stimulated heated debate on the matter. Conversely, once the Brexit result became public knowledge, import- and export-oriented UK companies reacted differently. Exporters' market prices did not show abnormal changes, while importers' prices seemed to be protected, in some way, by positive political speaking, which communicated that the UK and the EU would eventually negotiate a positive deal. We also found positive CARs for European 
export- and import-oriented companies, with a few exceptions, which show that investors selectively and differently priced the information on the referendum outcome, depending on the industry.

Finally, the positive CARs around the election of Theresa May for both UK and other European companies show financial markets interpreted the event as "good news". This can be explained considering that Prime Minister May was perceived as a trustworthy and credible politician, with a clear view on how to tackle the issue and lead the UK out of the Union. It initially appeared a new political stability would be achieved.

Text analysis of the articles concerning Brexit events largely supports the evidence shown by the event study. Mass media sentiment about Brexit (measured through the PMN indicator) was: i) very positive before the announcement of the referendum date but highly negative in the subsequent period; ii) slightly negative before the announcement of the referendum result and moderately positive in the subsequent period; and iii) slightly positive both before and after the election of Theresa May as Prime Minister.

Our cross-sectional analysis shows that investor reaction to different events related to Brexit depends more on industry factors than on firm-specific characteristics, both for UK and EU companies. The only exception is company size, which positively affects investor reaction in this and previous studies.

This paper makes several contributions to existing literature. It introduces a new focus on UK sectors that import from or export to the EU and European economic sectors that import from or export to the UK. It describes an event study on the effects of Brexit on the stock market, which considers different events around the referendum result, and thus allows a thorough observation of the stock market reaction to different levels and drivers of political uncertainty.

Our study also has important managerial implications. The results show that investors price political uncertainty differently, depending on the industry and its specific sensitivity to the economic consequences of political change. Conversely, idiosyncratic risk does not represent any specific determinant of abnormal price movements in the case of unexpected events. This may lead to the conclusion that managing political risk within corporate governance and Enterprise Risk Management systems, although important in order to anticipate ambiguity and volatility in the political environment, is not necessarily effective in preserving a company's reputation and economic value. Broader action initiated by industry associations, including enhanced media relations, might further help prevent negative market reaction and its effects on individual companies. Such an approach might be of utmost importance in the light of the current political instability in several European and Extra-European countries.

The present study investigates the effect of political uncertainty on several European stock markets. We consider Brexit as an event that produces instability, both in the UK and in other countries, which despite not experiencing a period of internal political instability, are affected by an exogenous political event. We believe that our work could be a starting point for future researches on the effect of Brexit - as an event of political uncertainty - focusing also on the role of mass media in the long period needed to allow the UK to exit Europe.

\section{References}

Aristeidis, S., \& Elias, K. (2018). Empirical analysis of market reactions to the UK's referendum results-How strong will Brexit be? Journal of International Financial Markets, Institutions and Money, 53, 263-286. https://doi.org/10.1016/j.intfin.2017.12.003

Baur, D. G., Dimpfl, T., \& Treepongkaruna, S. (2018). A Storm but No Damage? A Two-Country Equity and Currency Market Perspective of Brexit. Retrieved from https://papers.ssrn.com/sol3/papers.cfm?abstract_id=3144270

Begg, I. (2016, June). Brexit: why, what next and how? CESifo Forum, 17(1), 30-36.

Belke, A., Dubova, I., \& Osowski, T. (2018). Policy uncertainty and international financial markets: the case of Brexit. Applied Economics, 50(34-35), 3752-3770. https://doi.org/10.1080/00036846.2018.1436152

Białkowski, J., Gottschalk, K., \& Wisniewski, T. P. (2008). Stock market volatility around national elections. Journal of Banking and Finance, 32(9), 1941-1953. https://doi.org/10.1016/j.jbankfin.2007.12.021

Boehmer, E., Musumeci, J., \& Poulsen, A. (1991). Event-study methodology under conditions of event-induced variance. Journal of Financial Economics, 30, 253-272. https://doi.org/10.1016/0304-405X(91)90032-F

Boutchkova, M., Doshi, H., Durnev, A., \& Molchanov, A. (2016). Precarious politics and return volatility. Review of Financial Studies, 25(4), 1111-1154. https://doi.org/proxy.unimib.it/10.1093/rfs/hhr100

Brogaard, J., \& Detzel, A. (2015). The asset-pricing implications of government economic policy uncertainty. 
Managerial Science, 61(1), 3-18. https://doi.org/proxy.unimib.it/10.1287/mnsc.2014.2044

Campbell, J. Y., Lo, A. W., \& MacKinley, A. C. (1997). The econometrics of financial markets. Princeton: Princeton University Press.

Campello, M., Cortes, G., d'Almeida, F., \& Kankanhalli, G. (2018). Exporting Uncertainty: The Impact of Brexit on Corporate America.

Davies, R. B., \& Studnicka, Z. (2018). The heterogeneous impact of Brexit: Early indications from the FTSE. European Economic Review, 110, 1-17. https://doi.org/10.1016/j.euroecorev.2018.08.003

Deacon, D., Downey, J., \& Harmer, E., et al. (2016). The narrow agenda: How the news media covered the Referendum. In Jackson, D., Thorsen, E., \& Wring, D. (Eds.), EU Referendum Analysis 2016. Bournemouth: Centre for the Study of Journalism, Culture and Community.

Dibiasi, A., Abberger, K., Siegenthaler, M., \& Sturm, J. E. (2018). The effects of policy uncertainty on investment: Evidence from the unexpected acceptance of a far-reaching referendum in Switzerland. European Economic Review, 104, 38-67. https://doi.org/10.1016/j.euroecorev.2018.01.002

Goodell, J. W., \& Vähämaa, S. (2013). US presidential elections and implied volatility: The role of political uncertainty. Journal of Banking \& Finance, 37(3), 1108-1117. https://doi.org/10.1016/j.jbankfin.2012.12.001

Gros, D. (2016). The economics of Brexit: It's not about the internal market. Retrieved from https://www.ceps.be/publications/economics-brexit-it $\%$ E2\%80\%99s-not-about-internal-market

Harrington, S., \& Shrider, D. (2007). All events induce variance: analyzing abnormal returns when effects vary across firms. Journal of Financial and Quantitative Analysis, 42, 229-256. https://doi.org.proxy.unimib.it/10.1017/S002210900000226X

Hill, P., Korczak, A., \& Korczak, P. (2019). Political uncertainty exposure of individual companies: The case of the Brexit referendum. Journal of Banking \& Finance, 100, 58-76. https://doi.org/10.1016/j.jbankfin.2018.12.012

Jackowicz, K., Kozłowski, Ł., \& Podgórski, B. (2017). The distant echo of Brexit: Did exporters suffer the most? Finance Research Letters, 21, 132-139.https://doi.org/10.1016/j.frl.2016.11.012

Krause, T., Noth, F., \& Tonzer, L. (2016). Brexit (probability) and effects on financial market stability (No. 5/2016). IWH Online.

Levy, D. A., Aslan, B., \& Bironzo, D. (2016). UK press coverage of the EU referendum.

MacKinlay, A. C. (1997). Event studies in Economics and Finance. Journal of Economic Literature, 35, 13-39.

Mikkelson, W., \& Partch, M. (1988). Withdrawn security offerings. Journal of Financial and Quantitative Analysis, 23, 119-133. https://doi-org.proxy.unimib.it/10.2307/2330876

Moore, M., \& Ramsay, G. (2017). UK media coverage of the 2016 EU Referendum campaign. King's College London.

Oehler, A., Horn, M., \& Wendt, S. (2017). Brexit: Short-term stock price effects and the impact of firm-level internationalization. Finance Research Letters, 22, 175-181. https://doi.org/10.1016/j.frl.2016.12.024

Pantzalis, C., Stangeland, D. A., \& Turtle, H. J. (2000). Political elections and the resolution of uncertainty: the international evidence. Journal of Banking and Finance, 24(10), 1575-1604. https://doi.org/10.1016/S0378-4266(99)00093-X

Pastor, L., \& Veronesi, P. (2012). Uncertainty about government policy and stock prices. Journal of Finance, 67(4), 1219-1264. https://doi-org.proxy.unimib.it/10.1111/j.1540-6261.2012.01746.x

Pennebaker, J. W., \& Francis, M. E. (1996). Cognitive, emotional and language processes in disclosure. Cognition and Emotion, 10, 621-626.

Pennebaker, J. W., \& King, L. A. (1999). Linguistic styles: language use as an individual difference. Journal of Personality and Social Psychology, 6, 1296-1312. https://doi.org/10.1037/0022-3514.77.6.1296

Pennebaker, J. W., Chung, C. K., Ireland, M., Gonzales, A., \& Booth, R. J. (2007). The LIWC2007 Application. Retrieved from http://www.liwc.net/liwcdescription.php

Ramiah, V., Huy, N. A., \& Pham, M. I. (2017). The sectorial effects of Brexit on the British economy: early evidence from the reaction of the stock market, Applied Economics, 49, 2508-2514. 
https://doi-org.proxy.unimib.it/10.1080/00036846.2016.1240352

Schiereck, D., Kiesel, F., \& Kolaric, S. (2016). Brexit: (Not) another Lehman moment for banks? Finance Research Letters, 19, 291-297. https://doi.org/10.1016/j.frl.2016.09.003

Shahzad, K., Rubbaniy, G., Lensvelt, M. A. P. E., \& Bhatti, T. (2019). UK's stock market reaction to Brexit process: A tale of two halves. Economic Modelling, 80, 275-283. https://doi.org/10.1016/j.econmod.2018.11.013

Sharpe, W. F. (1963). A simplified model for portfolio analysis. Management Science, 9(2), 277-293. https://doi-org.proxy.unimib.it/10.1287/mnsc.9.2.277

Smales, L. A. (2015). Better the devil you know: The influence of political incumbency on Australian financial market uncertainty. Research in International Business and Finance, 33, 59-74. https://doi.org/10.1016/j.ribaf.2014.06.002

Smales, L. A. (2016). The role of political uncertainty in Australian financial markets. Accounting \& Finance, 56(2), 545-575. https://doi-org.proxy.unimib.it/10.1111/acfi.12107

Smales, L. A. (2017). "Brexit": A Case Study in the Relationship between Political and Financial Market Uncertainty. International Review of Finance, 17(3), 451-459. https://doi-org.proxy.unimib.it/10.1111/irfi.12100

Stone, P. J., Dunphy, D. C., Smith, M. S., \& Ogilvie, D. M. (1966). The General Inquirer: a Computer Approach to Content Analysis. MIT Press, Cambridge.

Tausczik, Y. R., \& Pennebaker, J. W. (2010). The psychological meaning of words: Liwc and computerized text analysis methods. Journal of Language and Social Psychology, 29(1), 24. https://doi.org/10.1177/0261927X09351676

Tielmann, A., \& Schiereck, D. (2017). Arising borders and the value of logistic companies: Evidence from the Brexit referendum in Great Britain. Finance Research Letters, 20, 22-28. https://doi.org/10.1016/j.frl.2016.08.006

Wielechowski, M., \& Czech, K. (2016), Brexit related uncertainty for United Kingdom economy. Oeconomia 15(4), 171-181.

\section{Copyrights}

Copyright for this article is retained by the author(s), with first publication rights granted to the journal.

This is an open-access article distributed under the terms and conditions of the Creative Commons Attribution license (http://creativecommons.org/licenses/by/4.0/). 